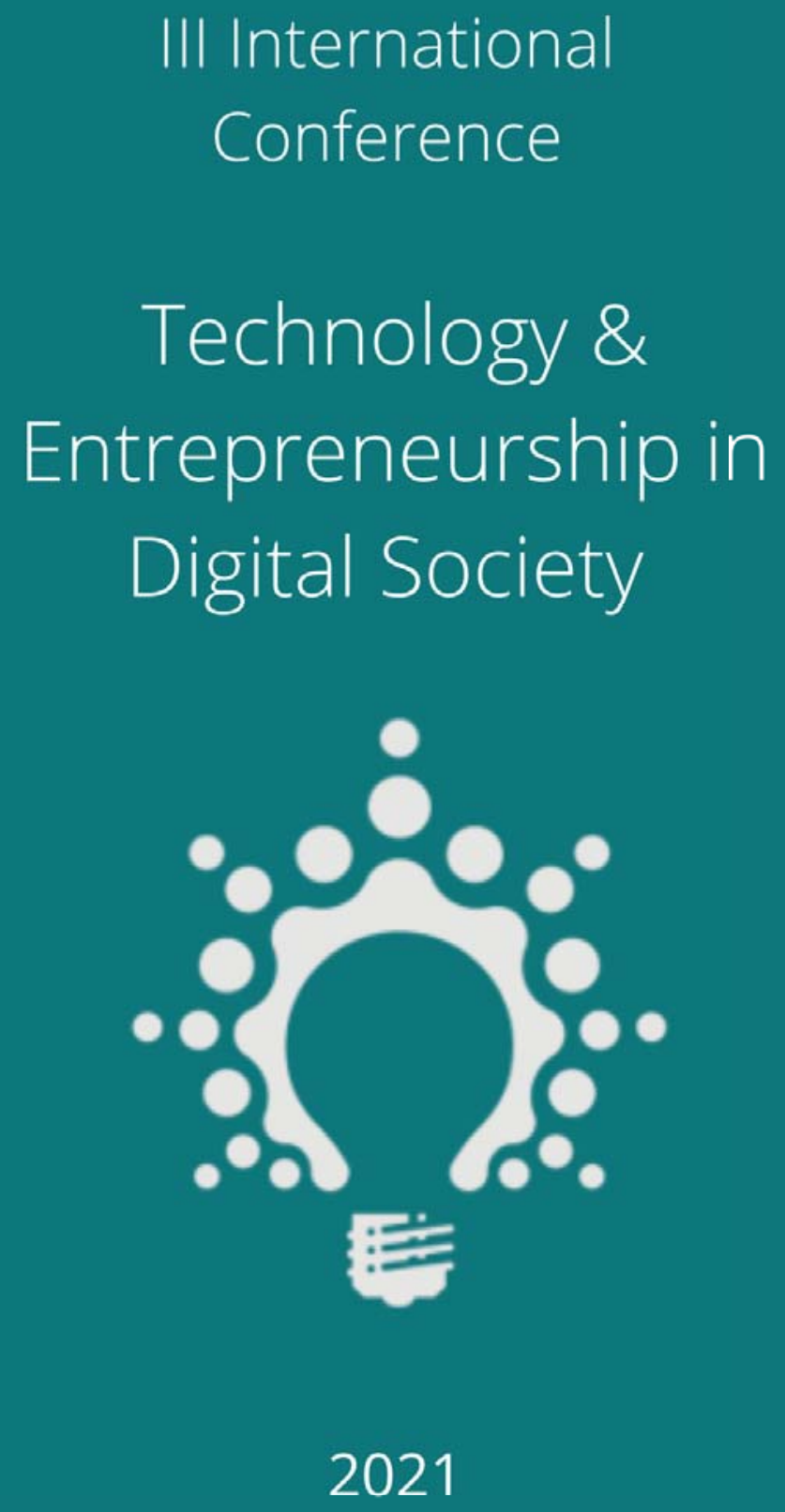


DOI: $10.17747 /$ TEDS-2020

The volume contains latest research work presented at III International Conference Technology \& Entrepreneurship in Digital Society 2020 (TEDS'20) held at Financial University under the Government of the Russian Federation, Moscow.

The conference aims to provide an opportunity for researchers, practitioners, and professionals from both the industry and the academia to share their newest research findings and results on technologies and their business applications in the digital era.

Permission to make digital or hard copies of portions of this work for personal or classroom use is granted without fee provided that copies are not made or distributed for profit or commercial advantage and that copies bear this notice and the full citation on the first page. Authors are able to enter into separate, additional contractual arrangements for the non-exclusive distribution of the proceeding's published version of the work (e.g., post it to an institutional repository or publish it in a book), with an acknowledgement of its initial publication in this proceeding.

Publisher - Real Economy Publishing House

Russia, 190020, Saint Petersburg, Staro-Petergofskiy prospect 43-45 B, of. 4.

Tel.: (812) 4954302, 3465015, Fax: (812) 3252099

www.jsdrm.ru, E-mail: info@jsdrm.ru 


\section{Content}

Biruta Svagzdiene, Arturas Simanavicius, Edmundas Jasinskas, Vilius Vasilius

LEISURE EVENT SITUATION DURING THE COVID-19 CRISIS PERIOD 4

Elena V. Vasilieva

DESIGN THINKING IS A METHODOLOGY FOR CREATING INNOVATIONS

AND DEVELOPING HUMAN CREATIVITY

Anton B. Georgievsky

CREATING ECOSYSTEM VALUE PROPOSITION BASED

ON SELLING SOLUTIONS IN THE DIGITAL ECONOMY

Irina V. Alyoshina

ARTIFICIAL INTELLIGENCE FOR UNIVERSITY MARKETING

Mikhail V. Zharikov

THE MODEL OF THE BRICS' SHARED INTEREST RATE

TO CIRCULATE A DIGITAL CURRENCY

Svetlana V. Karpova, Olga E. Ustinova

TRANSFORMATION OF CONSUMER BEHAVIOR

IN THE INDUSTRIAL MARKET IN THE CONTEXT OF DIGITALIZATION .28

Natalia L. Smith, Anton V. Antonov

DETERMINING THE DEGREE OF CULTURAL DISTANCE

IN DIVERSITY MANAGEMENT

Biruta Svagzdiene, Edmundas Jasinskas, Arturas Simanavicius A STRATEGIC FRAMEWORK FOR A LEISURE SERVICES BUSINESS MODEL IN THE SHARING ECONOMY .36 
DOI: $10.17747 /$ TEDS-2020-4-7

Biruta Svagzdiene ${ }^{1}$, Arturas Simanavicius, Edmundas Jasinskas, Vilius Vasilius

Department of Sports and Tourism Management

Lithuanian Sports University

Sporto st.6, Kaunas, Lithuania

'biruta.svagzdiene@1su.lt

\title{
LEISURE EVENT SITUATION DURING THE COVID-19 CRISIS PERIOD
}

\begin{abstract}
We are in the midst of an historic event COVID-19 that will change many aspects of our world. There will be major impacts on the global economy, geopolitics and our societies. It is clear that these global impacts and risks are highly interdependent and are changing the current and future global risk landscape
\end{abstract}

Keywords - Covid-19, leisure, organization of events, crisis

\section{INTRODUCTION}

In order to ensure good working activities of people, one of the most important things is quality leisure time. Leisure has a significant impact on the development and growth of the country's economy. Assessing the extent of the study of the problem of work, it can be said that there are very few generalized studies for the analysis of leisure sector event organization situations during crises, or they are only for the analysis of the situation of the world's largest events. Researchers [1] say research into the impact of the coronavirus crisis on the events sector is still a growing area of research

Purpose. To evaluate the Leisure event situation during the COVID-19 crisis period

Tasks:

To define the theoretical concept of leisure organization and events;

To discuss the results of the Covid-19 crisis for the leisure event organization service

Methods: Analysis of scientific literature and statistical data

\section{LEISURE AND EVENT ORGANIZATION SERVICES THEORETICAL CONCEPT}

The organization of events in the literature is defined differently. Often, the definition of an event depends on the category, purpose, tasks, location, financial resources, number of participants of the event and other less important factors [2].

The pandemic will inevitably worsen both within and between country inequality, as it will put at risk millions of relatively high-paying manufacturing and leisure sectors related jobs, depress wage earnings, and reduce government transfers and spending on social protection. The limited fiscal space - particularly in countries dependent on tourism and commodities exports - will constrain the abilities of governments to fight the pandemic and prevent massive jobs and income losses. Developing countries facing severe economic impacts will need substantial international support to avoid sharp increases in inequality.

Event Types: The What and the Why

The type of leisure events consists of educational, sports and recreation events. The type of cultural events consists of various religious events, ecclesiastical rites, events that foster cultural heritage and folk art. The type of events of the organizations consists of commercial, advertising, policy, charity events. The type of personal events consists of weddings, birthdays, namesakes, various annuals or other mentions. 
Fig.1 Types of events [3]

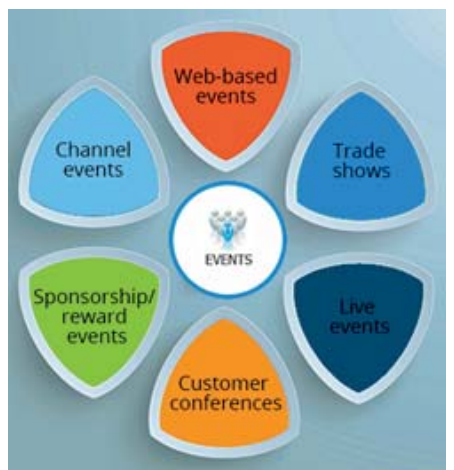

When examining literary sources about events, articles on the type of personal events, which include weddings, birthdays, namesakes, various annuals or other mentions, can also be found. Most articles can be found about the wedding. Scientists [4] say that organizing wedding events for wedding planners is a very important part of the organization of the wedding and will be even more important in the future. These researchers provide recommendations to professional wedding planners and stress that that people organizing such events have the following key skills: marketing (ability to manage customer relationships, customer service skills, understanding of the concept of consumer psychology behavior and sales technique), self-management (sense of responsibility, self-confidence, ambition, ability to resist pressure, emotion management, empathy), professional competence (ability to communicate, price knowledge, creativity, good planning skills, knowledge of space designs, understanding wedding rituals and customs), teamwork (team spirit, leadership, respect for others).

It is important to note, the sudden decline in economic activities due to the pandemic-induced lockdowns is affecting different sectors differently. The impacts are also asymmetric across different country groups, and depend on their economic structures.

Labour-intensive service sector jobs are most directly hit by lockdowns.

Retail trade, restaurants and hospitality, sports and recreations and transportation became the first casualties, as the pandemic containment measures largely shut down economic activities in these sectors, which employ millions of low-skilled workers.

The pandemic's impact hurts the low-skilled, low-wage workers both in formal and informal sectors the most, who are least able to withstand an economic shock.

Fig. 2 Events and their organization [5]

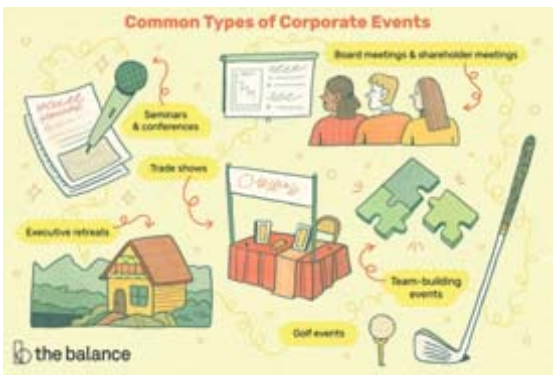


An event is an organized event that is planned, organized, run, and performed for a group of participants of a certain size. Events have a set duration of the event, which is usually scheduled and announced for planned events.

Event management involves overseeing all logistics leading up to and during an event, whether a conference, wedding, or any organized gathering. Event managers execute the event plans by managing staff, finances, vendor relationships, and more.

In the event planning profession, the job titles are as diverse and numerous as the services offered, and it can often be difficult to differentiate one from another. It can be challenging when preparing an event planning portfolio, looking for work, or working with a client who does not have the correct understanding of your job function and responsibilities.

\section{The theoretical concept of the crisis and its impact on the event industry}

According to the available data, more than 5,000 events have been canceled due to the Covid-19 virus emergency, in which not only employees but also freelancers have lost their jobs.

About half of the events are scheduled to be moved or will be canceled, or perhaps take another form. The amount of tickets to be returned to canceled or postponed events (so far) is almost 8.1 million. euros. Organizations that have not received planned revenue could reach about 9 million. EUR 3.8 million for self-employed persons. euros. Due to the state of emergency in the state, the organizations suffered about 6 million. together with those working under business licenses and individual activities - over 8 million euros. loss (losses were calculated with a 1-month quarantine) [6].

The creative sector is vulnerable and unprepared for such a sudden blow.

Now the whole creative community is concentrating on the experience of other countries and submitting proposals to the Government and the Seimas, cooperating with the Lithuanian Ministry of Culture and the Lithuanian Culture Council.

A package of government support and measures is expected to help the sector recover.

Proposals are being prepared, the sector and foreign experts are being consulted.

To sum up, it can be said that the impact of the crisis on events as a leisure services sector is limited. Most can be found in studies on the impact of the crisis on tourism, which includes leisure and events. However, due to the current global health crisis, caused by the Covid-19 virus, research sites are becoming a social, financial, economic and health impact on the countries and regions of the world. [7]. Leisure and event organizers, and especially managers, it is important to familiarize themselves with the problems caused by the health crisis, that their business of events and leisure services would be minimized in terms of health, social, financial and economic impact.

\section{CONCLUSIONS}

1. Organization of leisure is related with cultural, social activities, which include all companies and organizations developing cultural products and services. An event an organized event that is planned, organized, executed, and performed for a group of participants of a certain size.

2. Health crisis caused by Covid-19 virus made most of the event organizers of Lithuania in the research to cancel or reschedule most events. Sales of services of the majority of event organizers reduced significantly, while more than a fifth of event organizers had no income at all. Event organizers in most cases faced financial, psychological and communication difficulties.

3. From the point of view of event organizers, the situation caused by Covid-19 pandemic had a different effect on event organizers. The majority of event organizers suffered severe financial, economic and social impacts during the health crisis caused by Covid-19 virus. The organizers of cultural and leisure events were most affected financially. The main reasons for the decline in service sales include political decisions and fear of viewers and participants to become infected. Also, the vast majority of event organizers were not even prepared for crisis management and have not tried to transfer event business to virtual space. 


\section{REFERENCES}

[1] Mohanty, P., Himanshi, \& Choudhury, R. Events Tourism in the Eye of the COVID-19 Storm: Impacts and Implications. Event Tourism in Asian Countries: Challenges and Prospects (1st ed.): Apple Academic Press. 2020.

[2] Svagzdiene, B., \& Pupkis, A. Problems of organizing physical activity events in the work of leisure time organisers: why and how?. Humanities Studies, (2020), 3(80), 112-121

[3] Archer, J. VP, Principal Analyst Event Types: The What and the Why FEB 242015 , https://go.forrester.com/blogs/event-types-the-what-and-the-why/

[4] Han-Chen, H., Cheng-I, H., \& Yi-Syuan, H. Analysis of importance of the professional abilities required by personnel in wedding planner services. International Journal of Organizational Innovation, 2017, 9(4), 157-170.

[5] Hard, R. (2018). The Most Common Types of Corporate Events. Retrieved October, 1, 2018. Updated January 04, 2020 https://www.thebalancesmb.com/ corporate-events-common-types-1223785

[6] Jones, P., \& Comfort, D. The COVID-19 crisis and sustainability in the hospitality industry. International Journal of Contemporary Hospitality Management, 2020.

[7] Tuzovic, S., \& Kabadayi, S. The influence of social distancing on employee well-being: a conceptual framework and research agenda. Journal of Service Management, 2020. 
DOI: $10.17747 /$ TEDS-2020-8-11

Elena V. Vasilieva ${ }^{1}$

Department of Business Informatics

Financial University under the Government of the Russian Federation

Moscow, Russia

1evvasileva@fa.ru

\title{
DESIGN THINKING IS A METHODOLOGY FOR CREATING INNOVATIONS AND DEVELOPING HUMAN CREATIVITY
}

\begin{abstract}
Not so long ago, human resources were perceived as the main participant in business processes and as an integral part of the company's organizational capital. However, automation and the introduction of industrial technologies 4.0 replace people with programs, robots, chatbots, etc. But this does not mean that in the new era, human functions in the process will be reduced to a minimum. Goals focused on the implementation of new business tasks in the face of constant changes will require a person to work in a team, effectively use their competencies, be focused and successful, think outside the box and find original solutions, actively use the accumulated individual and collective intellectual capital. This will make the application of various techniques of the design thinking methodology an integral part of human activity in the company. The author gives an overview of the tools and techniques of design thinking, shows the features of their application. Highlights the specifics of organizing collective creative work and maintaining an atmosphere of trust and creativity. Provides a list of popular digital services for organizing teamwork. The development of the design thinking approach was achieved through the new methodology - Platform Innovation Kit, which is used for designing an ecosystem platform. Platform design canvases help startups and corporations launch and scale businesses on digital platforms.

Keywords - management; breakthrough innovations; soft skills; design thinking; creativity; Platform Innovation Kit
\end{abstract}

\section{INTRODUCTION}

In the context of digitalization of the economy and society, the requirements for the competence of specialists are changing. A modern organization needs an employee who is competent in their professional field, has knowledge of information technology, but most importantly - their skills of interaction with other people, emotional intelligence, empathy, teamwork skills, creative abilities and desires for self-realization and professional growth. Soft skills are extremely important today when performing professional tasks in an inaccurate initial formulation. They allow employees to move on to new tasks that are difficult to automate. And they help you quickly adapt to a changing environment.

You can also teach soft skills using one of the most discussed Design Thinking methodologies today.

\section{HOW TO CREATE BREAKTHROUGH INNOVATIONS?}

Design thinking is a methodology for designing innovative products based on technologies for managing people's collective intelligence and creativity. The author of this methodology is David Kelly, founder of the design Agency IDEO. Today it is developed at d.school (Stanford) and Hasso Plattner Institute (Potsdam). It combines various developments in the field of marketing and research of consumer needs, development of creative skills of a person and generation of ideas, visualization $[1,2,3]$. By applying design thinking, people learn to go beyond standard methods and established stereotypes when solving problems. They become creative and flexible in decision-making, feeling and emotionally fulfilled, understanding other people and themselves.

For more than 5 years, we have been actively implementing design thinking techniques in the educational process and applying it to solve adaptive problems both in the field of education 
for departments of the Financial University and its partners, and conducting design seminars at the invitation of organizations in various industries. Such design seminars allow you to develop teamwork and collaboration skills, mutual understanding and involvement in the problem of personnel, when creating a package of innovative ideas, team members also feel responsible for their implementation.

The integration of design vision and cognitive techniques allowed us to form a successful system for creating breakthrough innovations. The sequence of the design thinking process consists of several stages: from empathy and focusing on the problem-to generating ideas and choosing the best, and then - to developing a prototype and testing it. Popular tools include the Empathy Map, Customer journey map (CJM), How Might We (HMW), Current - Future-Barriers (CFB), SCAMPER, World café, etc. [4].

The empathy stage sets up the innovation developer to understand the consumer's emotions and feelings. He studies the client's problem, takes his place, looks at the product through his eyes. Partisan Ethnography is a method of covert observation of the target audience in real conditions. It includes a variety of techniques for collecting information, including photo and video shooting techniques, observing the user in a context where researchers spend the whole day next to a key

1 This line is reserved for Copyright Notice code representative of the target audience, literally walking behind them, or performing user tasks themselves using the "moccasins" technique.

One of the principles of Design thinking is to visualize and record ideas. Since the most important thing in the team's work during brainstorming is to hear, understand and briefly formulate any idea, and then be able to remember it after a while and convey it to an outsider, stickers and markers are indispensable assistants in the classroom. Visualization allows you to simply and clearly convey the meaning, present a new idea. Logical and visual thinking are activated simultaneously. For a visual representation of ideas in the IDEO building mind maps.

When studying the user experience, the entire chain of actions is studied and recorded in the outline of the CJM user path. Building a COM canvas is usually aimed at a detailed description of the process with the identification of the emotional component of its participants, as well as at developing scenarios to eliminate barriers to the user's business tasks. Each stage of the analyzed process can be divided into four categories (PEDPL model): previous experience - PreExperience; problems of current experience - During Experience; results after completion - Post-Experience, as well as missed alternatives, lost Experience - Lost Experience [4].

The project team can fill in the COM outline manually on a flipchart sheet using stickers, in Google spreadsheet, and in archi Internet services, miro.com (Fig. 1), mural.ly, uxpressia.com.

Fig. 1. Example of a CRM tool: Miro.com

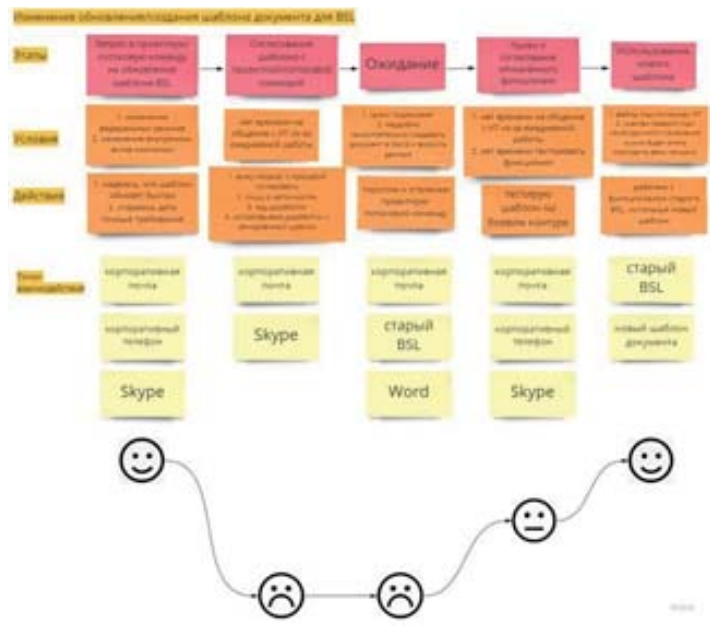


During the "Generation" stage, a large number of possible solutions are created during brainstorming. At this stage, the techniques work well: How Might We, Current - Future - Barriers, SCAMPER, and World café [4].

\section{THE PLATFORM DESIGN METHODOLOGY}

A new platform design methodology has been developed and is Being successfully tested in practice for designing an ecosystem platform. This Is Platform Innovation Kit [5,6].

All scenarios of using the company's products or services, including joint offers with partners, create a special ecosystem

Today, many companies that have chosen digital transformation as their main strategy are moving to a new paradigm of ecosystem platform thinking, which defines the requirements for how to build working processes and solutions. Companies such as Sberbank, Yandex, and others are developing consumer services as an ecosystem. Mail.ru Group.

The basis of the ecosystem is still the platform. The ecosystem has open interfaces or provides compatibility of various services, its functionality includes identification services, rapid data exchange, etc., and unified software interfaces make it easier to connect to the platform.

The European payment Directive PSD 2, aimed at increasing competition in the payment services market, gave a boost to the ecosystem. With its approval, banks began to provide open access to the API (Application Programming Interface - the application Programming Interface that developers can use to create their own applications to work with the service). Providing services in an open format (open banking) has increased competition, forcing us to look at the possibilities of the value proposition more broadly. The Bank is integrated into the value chain in many segments through the ecosystem, and in return, partners get access to customer data.

Cutting-edge companies aim to improve the experience for their customers, not only in their field, but throughout their life. Therefore, their new offers are built around possible customer needs for non-core services. An ecosystem based on the "LifeStyle Banking" principle, where a single mobile banking app can cover almost $100 \%$ of a client's potential needs in any area of life - from buying groceries to renting a home, etc. According to this strategy, banks are starting to conduct projects in healthcare, education, retail, and partly transport.

The Sberbank ecosystem, for example, spanned several verticals at once. If in 2019 it included 20 different companies, now there are already 48 ecosystem projects, including education (Business environment), employment (Rabota.ru), telemedicine (together with DocDoc), online Commerce (Yandex.Market, Bringly), food delivery (together with Mail.Ru - DELIVERYCLUB), real estate, etc.

Platform design canvases help startups and corporations launch and scale businesses on digital platforms. This methodology contains a number of visual templates (canvases) that allow designers to collect key transformation ideas at different stages of design, closing the white spots of uncertainty, and move towards the goal, including creating knowledge bases for future projects. Canvases, in fact, allow you to draw a business layout. Visualization enables the project team to work effectively, reduce the risk of data loss, and support the creative process.

Platform Innovation Kit tools include: Platform-BusinessModel, Platform Mapping, PlatformStakeholder-Relationship, Ecosystem-Journey, Context study canvas, StakeholderPersona, Platform-Architecture.

At the research stage, ecosystem objects are described and the organization's potential is analyzed. A good and simple framework for displaying existing benefits (assets) for an organization is the VRIO framework. The map of the platform communication ecosystem reflects the relationships between end and intermediate peer-to-peer (peer-to-peer) consumers (PC) and producers (PP), partners (RA), and platform owners (PO).

The potential and motivation matrix compares all current and potential value flows to understand what one ecosystem participant can give to another. All schemas serve as the basis for the Platform Business Model Canvas. 


\section{CONCLUSION}

The platform strategy is an "interactive" product, and with the generation of network effects, the value of the platform usually increases. These tools allow you to generalize available materials, formulate development hypotheses, identify participants and their relationships in the process of delivering a service (product) to the consumer along the entire path of contact with the brand. Platform design, as well as customer experience design, currently only acquire their own tools and techniques, but now we can talk about the diversity and benefits of visual schemes of design thinking and Platform Innovation Kit for management and innovation.

Design thinking opens up good prospects for finding innovative ideas both in the course of collective intellectual work and in independent creativity. The effectiveness of brainstorming is provided by structuring information using various canvases. The activity of thinking is supported by the workouts and switching to the other steps of research, discussion or development of the prototype. Iteration of the process and positive feedback reduces risk aversion and teaches you to analyze errors. Different thinking styles are involved. Design thinkers are able to trust their intuition, turn on their imagination, think outside the box and not stop there. Thus, design thinking is an important tool for human development and is necessary for implementation in the educational process and practice of working with personnel.

\section{REFERENCES}

[1] T. Kelley, D. Kelley, Creative Confidence Unleashing the Creative Potential Within Us All. NY: Barnes \& Noble, 2013.

[2] J. Liedtka, T. Ogilvie, Designing for Growth: A Design Thinking Toolkit for Managers. Columbia University Press, 2011.

[3] M. Levrik, P. Link, L. Leifer, The Design Thinking Playbook: Mindful Digital Transformation of Teams, Products, Services, Businesses and Ecosystems. NY : Wiley, 2018.

[4] E. Vasilieva, Design thinking: a little bit about the approach and a lot about the tools of creative thinking, learning client requests and creating ideas: monograph. Moscow: RU-SCIENCE, 2018. (In Russ.)

[5] 12 Patterns of Platform Design to kickstart Innovation Strategies. Available at: https:// stories.platformdesigntoolkit.com/12-patterns-ofplatform-design-to-kickstart-innovationstrategies-500c6dec9c3b (accessed 02.09.2020).

[6] Platform Design Toolkit. Available at: https://ab-w.com/method_meetup/ platform_design (accessed 02.09.2020). 
DOI: $10.17747 /$ TEDS-2020-12-16

Anton B. Georgievsky ${ }^{1}$

Graduate School of Business

National Research University Higher School of Economics

Moscow, Russia

1520789@mail.ru

\title{
CREATING ECOSYSTEM VALUE PROPOSITION BASED ON SELLING SOLUTIONS IN THE DIGITAL ECONOMY
}

\begin{abstract}
The development of digital technologies and the ongoing coronavirus pandemic contribute to expanding the company's opportunities to provide a complete value proposition to the client. The purpose of this article is to determine groups of components of the value proposition based on selling solutions in the ecosystem and identify strategies that allow creating such a value proposition in the digital economy. The research method is based on the analysis of academic and consulting literature. As a result of the research, groups of components of the value proposition based on selling solutions in the ecosystem were formed, and strategies for the formation of the value proposition were identified. These results will help researchers build new models of the value proposition, and entrepreneurs form value propositions that fully satisfy customer needs.

Keywords - ecosystem; value proposition; components; strategies; coronavirus pandemic; consumer trends; solutions; selling solutions; digitalization; digital economy; ecosystem value proposition; customer needs
\end{abstract}

\section{RESEARCH QUESTION}

The digitalization of existing processes in the economy leads to an increase in the consumer's role in forming the value proposition. Traditional sales offer customers separate products or services, considering the customer needs rather narrowly. Companies understand that a great potential for business development in the digital economy lies in complete customer satisfaction. For this purpose, the company can use selling solutions. The development of digital technologies, in particular big data, the Internet of Things, and sensors, allows the company to know its customers much better and interact with them closer than ever. Often, the company alone is difficult to offer a complete solution to the client's problem. Therefore, the company forms an ecosystem in which a group of actors, including the client, creates a joint value proposition.

Although the concepts of selling solutions, value proposition, and ecosystem are quite popular, integrating these topics in one study is given very little attention in the academic literature. Among the key issues of a value proposition is the identification of its components and strategies for its formation. This article aims to determine groups of components of the value proposition based on selling solutions in the ecosystem and its formation strategies.

These findings will help companies create a competitive advantage and increase their profits. Researches will receive conceptual models to create new models of the ecosystem value proposition.

\section{LITERATURE REVIEW}

This work links three related concepts: selling solutions, value proposition, and ecosystem.

The concept of selling solutions has become especially popular in recent years due to the development of the service lens [1] that integrated the ideas of service-dominant logic [2] and the concept of jobs to be done [3]. The service lens focuses not on the resources of only one company, but the resource integration between different actors in the value co-creation process. The development of the service lens allowed the company to look at customer problems more broadly and pay more attention to interaction with clients. The shift to value cocreation implemented within the servicedominant logic has opened up the opportunity to analyze a value-in-use context that contains many previously unrevealed customer needs and potential sources of strategic advantage. 
Traditionally, the concept of a value proposition has been viewed in terms of product logic. The value proposition was unidirectional, and the value was built into the product by the manufacturer. A key goal of the value proposition was to reflect the product's advantages over the competitors. With the development of service-dominant logic, the value proposition began to focus on the interaction process of value creation. Modern value propositions go beyond the established supplierclient relationship and include many stakeholders or actors [4].

As the researchers note, ecosystems are a possible option for providing solutions [5]. They are characterized by a high degree of modularity and the need for coordination between participants. At the same time, this organizational form is distinguished by the absence of a full hierarchy control, which allows companies to be flexible when forming a value proposition [6]. Actors strive to find an optimal position in the ecosystem with a balance between the value generated for the ecosystem and the value created for the participant.

According to the structural perspective of the ecosystem [7], the value proposition determines ecosystem design [8] and required partners for the realization of the value proposition. It is essential to understand that the client is an ecosystem actor actively involved in value creation. Moreover, according to the service-dominant logic, the value is determined by the client [9]. It is important to note that the client's ability to co-create value increases with the opportunities provided by digital technologies [10].

Thus, accompanied by the development of the digital economy, the integration of these concepts is a necessary step to fully meet customer needs.

\section{THEORETICAL GROUNDING AND METHODOLOGY}

One of the most popular models describing value formation in the ecosystem is the Ecosystem Pie Model proposed by Talmar et al. [11]. This model serves as a response to the request for a structural approach to creating an ecosystem [12]. The model describes the structure of the ecosystem and considers the activities of key actors. The value proposition is the core element of the model. There are two main features of this model. First, it considers value both at the ecosystem level and at the company level. Secondly, it allows the visual depiction of the relationships between the actors involved in value co-creation. Despite the comprehensive approach to value formation, this model does not consider the components of the value proposition, strategies for its formation, and selling solutions as a particular case of value proposition creation.

A meta-analysis of academic and consulting works was used to determine groups of components of the value proposition based on selling solutions in the ecosystem. At the first stage, a list of academic papers containing value proposition models was formed based on scientific citation databases. After that, the components of the value proposition were selected from each model. As a result, a general list containing the components of the value proposition was obtained. Then the considered components were ranked by the number of mentions in the authors' works. The considered components and models of the value proposition were classified based on several approaches. Based on the study of the literature on selling solutions and ecosystems, the most suitable components for forming the value proposition based on selling solutions in the ecosystem were identified among the proposed list of components. The components were formed into several groups, which were considered to create the value proposition in the digital economy.

In order to determine strategies for forming the value proposition based on selling solutions in the ecosystem, an analysis of academic and consulting literature on the three topics of interest was used.

\section{EMPIRICAL ANALYSIS}

The study presents four groups of components of the ecosystem value proposition based on selling solutions. The groups are designed for using digital technologies at each stage of solution development. 
The first group includes components focused on the process of providing a solution to the client. Here, the client's convenience becomes the key task of the ecosystem. The components of this group are based on concepts such as customer journey and customer experience. Augmented reality and virtual reality blur the line between brick-and-mortar and digital and make interaction with the ecosystem more valuable. The ecosystem should provide the convenience of touchpoints and demonstrate the advantages of the solution compared to competitors. The ecosystem can offer its customers omnichannel using a well-developed infrastructure of actors. Moreover, drones and robots are capable of enhancing fulfilment efficiency and speed up delivery.

The second group is aimed at achieving the client's goal. Customers, especially in B2B markets, can monitor the provided solution very carefully. Various sensors of the Internet of Things provide lots of opportunities for this purpose. At the same time, the effectiveness of the solution provided for the client's problem is a necessary attribute of the solution in B2C markets. Clients do not want to see the solution itself, but the result that they get from using it. Only in this case, the provided solution will make sense. Often, the client does not even own the property right, but uses the solution by subscription or pays for the time of use. The SaaS (Software as a Service) model can serve as a means of providing such solutions. It is worth noting that a payment-forresults model is widely used in selling solutions, ensuring the solution's effectiveness for customers.

The group of communication components gets unprecedented opportunities for development due to the spread of digital technologies. Companies are constantly present in the clients' lives, communicating with them in social networks and messengers. This group of components correlates with the development of the relational paradigm in marketing, which focuses on the interaction between the company and the client, joint value creation, and orientation on building long-term relationships. The constant use of the smartphone by clients creates opportunities for ensuring regular contact between the company and the client through applications and technologies. Using beacon technology and GPS data helps clients stay connected. It is important to note that despite the digitalization of most processes, personal communication between customers and employees is still critical.

The fourth group of components allows the company to determine how widely the company considers the client's problem and offer the client a personalized solution. It is important to emphasize that it is the client who determines what is valuable. Personalized value is based on the client's deep knowledge, the analysis of big data, and the flexible configuration of the processes that form the solution.

The crucial task for solutions is to take a broad view of the client's needs. This fact opens up opportunities to offer the client various related offers. It is especially promising for building longterm relationships with the client. In this case, the solution to all problems within a specific need for the client will be associated with a specific ecosystem. The clients leave much information about themselves by interacting with the company through the personal communication, app, site, community, and loyalty programs. Based on big data analysis, artificial intelligence can predict what services a customer may need and when. Fig. 1 depicts the proposed groups of components.

Fig. 1. Groups of components of the ecosystem value proposition based on selling solutions.

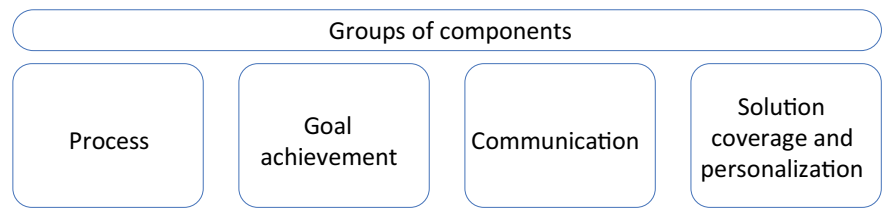


The study identifies strategies for creating the value proposition based on selling solutions in the ecosystem. The strategies vary according to the extent of their coverage.

The company can view the market as broadly as possible and offer various loosely coupled solutions to different clients. In these conditions, it is critical to have a digital platform that allows the company to combine all solutions in one place and make them convenient for the client. Most often, this strategy is used by companies operating in the information technology and banking sectors. It requires significant resources and a large client base.

Another option is to meet the needs of a specific group of customers. In this case, the needs become linked, and the company provides the customer with many related solutions. A significant role here is played by analyzing customer data to better understand customers and using artificial intelligence to provide solutions that may be of interest to them from several related areas covered by the ecosystem. In addition to the main offer of goods and services, the company may provide education services, personal recommendations, and other solutions for each day.

The most concentrated strategy is to focus on the complete satisfaction of one customer need. The strategy requires a high degree of coordination of all ecosystem participants, which involves using digital technologies to constantly exchange data on the progress of the solution. The ecosystem can use cloudbased services that collect and analyze huge volumes of data. It reduces costs and makes the ecosystem more flexible. As a rule, this strategy is implemented by small ecosystems that can perform all tasks within a specific need better than other market players.

The company chooses a strategy based on the capabilities of the ecosystem participants and the potential market (Fig. 2).

Fig. 2. Strategies for creating the ecosystem value proposition based on selling solutions.

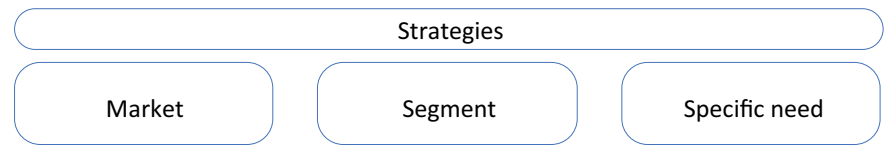

The proposed groups of components and strategies for forming the ecosystem value proposition based on selling solutions help practitioners and researchers create value propositions and their models that will allow companies to be profitable in the digital economy.

\section{REFERENCES}

[1] L. Bettencourt, R. Lusch, and S. Vargo, "A service lens on value creation: marketing's role in achieving strategic advantage," California Management Review, vol. 57, pp. 44-66, 2014. doi: $10.1525 / \mathrm{cmr} .2014 .57 .1 .44$

[2] S.L. Vargo and R. Lusch, "Evolving to a new dominant logic for marketing," Journal of Marketing, vol. 68, pp. 1-17, 2004. doi: 10.1509/jmkg.68.1.1.24036

[3] T. Ulwick, "What is jobs-to-be-done?," URL: https://jobs-to-bedone.com/ what-is-jobs-to-be-done-fea59c8e39eb

[4] P. Frow et al., "Value propositions: a service ecosystems perspective," Marketing Theory, vol. 23, pp. 1-25, 2014. doi: 10.1177/1470593114534346

[5] J. Stonig and G. Müller-Stewens, "Navigating the challenges of ecosystem emergence: a multi-level review of leader and complementor strategies," Die Unternehmung, vol. 73, no. 4, pp. 288-307, 2019. doi: 10.5771/0042-059X-2019-4-288

[6] M. Jacobides, C. Cennamo, and A. Gawer, "Towards a theory of ecosystems," Strategic Management Journal, vol. 39, pp. 2255-2276, 2018. doi: 10.1002/smj.2904 
[7] R. Adner, "Ecosystem as structure: an actionable construct for strategy," Journal of Management, vol. 43, no. 1, pp. 39-58, 2017. doi: 10.1177/0149206316678451

[8] U. Pidun, M. Reeves, and M. Schüssler, "How do you "design" a business ecosystem?," URL: https://www.bcg.com/publications/2020/how-do-you-design-a-businessecosystem

[9] S.L. Vargo and R. Lusch, "Service-dominant logic: continuing the evolution," Journal of the Academy of marketing Science, vol. 36, pp. 1-10, 2008. doi: 10.1007/s11747-007-0069-6

[10] E. Marcon et al., "Barriers for the digitalization of servitization," Procedia CIRP, vol. 83, pp. 254-259, 2019. doi: 10.1016/j.procir.2019.03.129

[11] M. Talmar, B. Walrave, K. Podoynitsyna, J. Holmström, and G. Romme, "Mapping, analyzing and designing innovation ecosystems: The Ecosystem Pie Model," Long Range Planning, vol. 53, no. 4, 101872, 2020. doi: 10.1016/j.lrp.2018.09.002

[12] D. Hannah and K. Eisenhardt, "How firms navigate cooperation and competition in nascent ecosystems," Strategic Management Journal, vol. 39, pp. 3163-3192, 2018. doi: $10.1002 / \mathrm{smj} .2750$ 
DOI: $10.17747 /$ TEDS-2020-17-21

Irina V. Alyoshina

Department of Marketing

State University of Management

Moscow, Russia ialyoshina@gmail.com

\title{
Artificial Intelligence for University Marketing
}

\begin{abstract}
Artificial intelligence (AI) is embedded in digital marketing technologies and so facilitates the development of university marketing management. The article discusses digital globalization trends and factors influential for AI deployment in higher education.

Keywords - artificial intelligence; higher education; digital globalization; marketing; digitalization; platformization
\end{abstract}

\section{ARTIFICIAL INTELLIGENCE FOR THE 21-ST CENTURY}

Artificial Intelligence (AI) can be defined in a wide sense as "the scientific understanding of the mechanisms underlying thought and intelligent behavior and their embodiment in machines." [1]. Accenture regards artificial intelligence as "a constellation of many different technologies working together to enable machines to sense, comprehend, act, and learn with human-like levels of intelligence" [2]. In practice, AI represents software technologies that allow computers and robots to perform some human work faster, more accurately, and in greater volumes. So, accuracy, capacity and speed are often the benefits of $\mathrm{AI}$ in comparison with common human performance. In case of need for large amount of information processing AI saves time, money, space, human and other resources.

AI technologies are basically used for recognition and generation of objects (images, texts, sounds, smells, events and others). AI is an umbrella term for a range of technologies, - data mining, machine learning, natural language processing, neural networks or an algorithm [3].

It is quite difficult today to reveal the sphere of contemporary economy, society and human life unaffected yet with AI technologies. Industrial manufacturing, energetics, transportation, communications, government services, healthcare and social care, education and entertainment are already use some AI decisions. AI is seen as the core technology for an age of digital globalization in the 21-st century [4]. Industry 4.0 and Fourth Industrial revolution restructures the labor markets, eliminating some jobs, changing others and create new professional positions for developers and qualified users of AI technologies.

Universities are also depend on AI development because of their intelligence-intensive activities (teaching, learning, research, management of academic activity) and because of targeting knowledge intensive labor market.

\section{HIGHER EDUCATION DEVEPOPMENT TRENDS}

Sphere of higher education (HE) is currently influenced by a number of interrelated trends:

1. Globalization of markets and resources

2. Massification of higher education

3. Commodization of higher education

4. Democratization of information

5. Digitalization and digital transformation

6. Socialization and Networkization 7. Platformization of business models.

Globalization of markets means growing demand for internationally and globally oriented workforce, able to be employed in international and transnational companies in different countries and regions of the world. Universities compete for the best positions in the world university ratings, for partnerships with global companies and for international students. New technologies conquer global markets and create global demand for specialists ready to work with or on AI systems. 
Massification of $\mathrm{HE}$ is the consequence of technological progress and intellectualization of character of jobs. Mass demand for higher education means more people enter universities in hope to receive better chances for employment after graduation. So more people need to be educated and lifelearning has become a reality. Automation of universities' operations serves the purposes of scaling and cost reduction.

Commodization of HE appeared in parallel with massification of it. If you need to teach large amount of people you have to decide how to do it more easily, how to make complex product available to many people with quite uneven learning abilities. Electronic forms for textbooks, cases, tests and learning software serve the purposes of commodization.

So, MOOC (massive open online courses) appeared as a response to the demand of massification and commodization supported with digitalization trend. The availability of MOOC for global audiences and growing involvement of students in learning value creation have democratized education.

Socialization and networkization of business activity thanks to social media services have expanded social dimension of HE. The majority of students are interconnected through several social networks. Social and networked character of HE was revealed during involuntary transition of universities to distance form of teaching and learning. Universities all over the world used global networking online services - Zoom, Google classroom, Facebook, MS Teams, Skype and others, - for educational, scientific and administrative activities. The leading global techguants use multisided platform business model, connecting different markets with software technologies. Global digital platforms (including learning ones, - Coursera, EdX), - integrate vendors and consumers, supporting global value chains. National, international and global platformization can be seen as perspective dimension for university development. Functioning of global digital platforms depends on AI technologies for big data processing, analytics, customer relationships management, advertising, public relations and marketing.

\section{MARKETING DEVEPOPMENT TRENDS}

Contemporary marketing is seen through holistic approach and is regarded as holistic marketing [5]. American Marketing Association definition sounds as "Marketing is the activity, set of institutions, and processes for creating, communicating, delivering, and exchanging offerings that have value for customers, clients, partners, and society at large [6]".There are four basic dimensions, or components of holistic marketing activity:

1. Integrated (traditional) marketing, - external consumer-, or externally, oriented

2. Internal marketing, targeting employees, or internal audiences of organization as internal consumers

3. Society-oriented, social responsible marketing.

4. Partnership, or relationship, marketing, targeting partners (suppliers of parts and services, helping to create value for customers).

The basic elements of holistic marketing mix as basic components of any marketing decision are $[5]$ :

1. People (consumers, employees, partners, and community/ society)

2. Processes (operations, business-processes)

3. Programs (includes traditional marketing mix: product, price, place, promotion)

4. Performance (marketing, financial, social, technological achievements)

The same business-related trends, noted above are also common for contemporary marketing. Therefore, business practice demonstrates the evidences of:

1. Globalization of marketing activities and operations, targeting (or at least taking in account) international and global markets

2. Massification, commodization and democratization of marketing activities. Some today's marketing technologies (internet marketing and advertising; online survey, or 
questionary, research, social media marketing) are available for small business and individuals, not only for marketing agencies and professionals.

3. Digitalization of marketing is the result of growing internet-access penetration and of technologies' development.

4. Socialization and networkization of marketing we see, using social media services.

5. Platformization of marketing. Platform business models' expansion means the increasing role of marketing on digital platforms, supporting job search, selling goods and services. Multi-sides markets are integrated with platform marketing.

Digitalization of marketing operations is closely interconnected with AI technologies. According to AMA,

"Digital marketing" refers to any marketing methods conducted through electronic devices. This includes online marketing efforts conducted on the internet [7]". The basic methods for conducting digital marketing named there are:

1. Search Engine Optimization (SEO)

2. Search Engine Marketing (SEM)

3. Pay-Per-Click (PPC)

4. Social Media Marketing (SMM)

5. Email Marketing

6. Affiliate Marketing

7. Content Marketing

8. Native Advertising

The majority of these methods depends on AI already integrated in online services (search engines, social media, context advertising). Further digitalization of business processes increases the possibilities for the usage of AI. At the same time IT- infrastructure underdevelopment decreases the chances for digitalization and AI deployment. Anyway, digitalization is common trend, so higher education and universities are supposed to undergo digital transformation, even if involuntarily and from outside if not voluntary and from inside.

\section{ARTIFICIAL INTELLIGENCE , UNIVERSITY AND MARKETING}

The role of AI for university's marketing and management can be presented as intermediation between last two and digital marketing management (Figure 1). Digital marketing to be successful needs large amount of data processing for real-time decision-making. At the same time part of university marketing operations (special events, conferences, discussions, meetings, personal selling) are hold off-line, but anyway are influenced by digital marketing (SMM, SEO, internet advertising, internet public relations, database marketing).

Fig.1. Artificial intelligence and university marketing

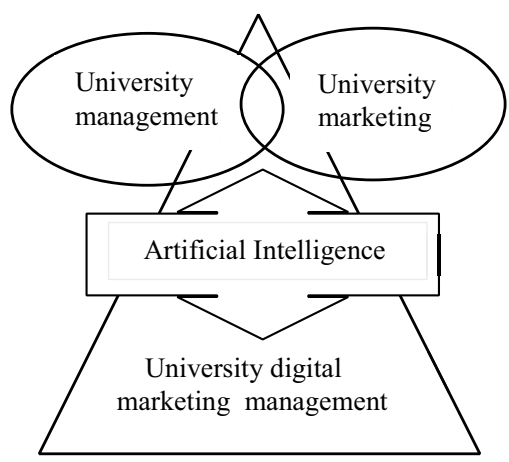


In fact all kinds of university activity, - teaching and learning, scientific research, administrative, - make sense for marketing as soon as they create customer or stakeholders' (students', professors', employees', partners' and society's), experience and so influence university reputation and position at the market of education and research. The basic spheres of AI application for university can be defined as:

1. Institutional and administrative levels (marketing and recruiting, admission and enrollment, curricular and resource planning, administrative and financial student support [3], [8]

2. Teaching and learning (student-facing functions; automatic delivery and teaching course content; diagnosing strengths and automated feedback; curating learning materials; "personalized learning" facilitating collaboration and the teacher's perspective (teacherfacing functions) - [3], [8]

3. Scientific research (automatic systematic academic literature reviews, checking plagiarism and misuse of statistics, flagging unethical behavior [9]. In science, AI technologies reduce the cost of gaining insights and of predictive analysis; find connections, autonomously create hypotheses. AI can deepen understanding of specific spheres of knowledge, facilitate cross-boundaries integration of ideas and crossdiscipline collaboration.

According to holistic marketing approach, all dimensions of AI applications make sense for University marketing, sharing data and information for decision-making.

Positive aspects of using AI in university can be defined as:

1. Effectiveness. AI processes much more information than humans, does it in a real time and with more accuracy. Less mistakes may be done and decisions could be more accurate. This helps to make learning, teaching, guidance, research and institutional decisions more effective.

2. Efficiency. Automation of routine tasks saves costs, efforts and frees up time for creative decisions. Resource pressure becomes more evident for universities because of economic difficulties during pandemic of covid-19.

However, AI is not cure-for-all [10], there are some weaknesses of AI in HE:

1. Narrow character of AI, not general in comparison with human capacity and intelligence. $\mathrm{AI}$ is task-specific and is unable to function in new context or be applied for different type of tasks.

2. The quality of algorithm depends on quality of data collected. Data may be outdated or not new enough. It may be focused on the subset of population not close enough for students (professors, employees) group targeted. In case situation changes, suppose because of covid19, AI doesn't work as previously expected. Algorithm's implicit bias may be a real problem. That is why algorithmic outcome may be disparate. Therefore, people using AI are expected to be knowledgeable enough "to trust or question the algorithmic output [8] ".

3. Huge amount of information is needed for machine learning, dozens of thousands of patterns may need to be collected. So AI may benefit more for large open, or online, universities than for small and medium-size universities.

4. Privacy and data protection may be in question. AI systems sometimes require confidential information. Employees, students and professors may resist providing their personal information (style of learning/teaching, cognitive abilities, health or family situation) for assessment and managerial decision-making.

5. Negative perception of AI by employees if they expect machines could replace them. People need to know how AI impacts their lives.

6. AI could hardly be used without human supervising and control. The society is still not ready yet for driverless education 
In search of digital instruments for increasing competitiveness and reducing cost it is important to keep in mind that "much advanced learning, and its assessment, requires personal and subjective attention that cannot be automated" [9]. So there are still some limitations for automation of intelligence. In order to implement AI technologies [8] for university marketing management one should be prepared to answer the following questions:

1. What functions and roles does the data perform? How it can be used responsibly?

2. What decisions of AI "black box" we do not see? Categorization and visualization of data are the keys for decision making, not only computing.

3. Who is in control of content used by AI? Is it administration, or technology provider, what about students, professors and external audiences?

4. How the outcomes of AI are supposed to be checked for adequacy, effectiveness, context dependence and limitations? How positive and negative outcomes can be measured?

5. What do we loose with datafication? And should and how can we compensate it?

6. What are the priorities for AI implementation? How and whose interests are prioritized?

In an age of digital globalization we can expect the further development of university digital marketing management, that is the expansion of technology in marketing-oriented university management. Digital marketing management today depends on AI. Successful implementation of AI for university marketing demands holistic and inclusive conversation on its fit to university's and higher education's mission.

\section{REFERENCES}

[1] Association for the Advancement of Artificial Intelligence (AAAI.). AI definition. https:// aitopics.org/search

[2] Artificial Intelligence definition.Accenture. https://www.accenture.com/us-en/insights/ artificial-intelligencesummary-index

[3] Zawacki-Richter O., Marín V.I., Bond M., Gouverneur F. Systematic review of research on artificial intelligence applications in higher education - where are the educators? // International Journal of Educational Technology in Higher Education, 28 October, 2019, https://doi.org/10.1186/s41239-019-0171-0

[4] Alyoshina I.V. Artificial Intelligence in an Age of Digital Globalization. /Technologies and Entrepreneurship in Digital Society Proceedings of Intern. Conf TEDS-19, Nov 13, 2019. Saint Petersburg: Real Economy Publishing House, 2019, 68 p., pp. 26-30 https:// managementscience.ru/site/public/elfinder/TEDS2019/TEDS2019-26-30-Alyoshina.pdf DOI: https://doi.org/10.17747/TEDS-2019-26-30

[5] Kotler P., Keller K. Marketing Management.14th Edition. Prentice Hall, 2012, - 816 p.

[6] Definition of Marketing. American Marketing Association. Approved, https://er.educause. edu/articles/2019/8/artificial-intelligence-in-higherJuly 2013 and 2017. Available at: https://www.ama.org/the-definition- education-applications-promise-and-perils-andethical-questions of-marketing/.

[7] What is Digital Marketing. American Marketing Association. Here's how. https:// www.weforum.org/agenda/2017/08/artificialhttps://www.ama.org/pages/what-is-digitalmarketing/ intelligence-will-transform-universities-here-s-how/ 09 Aug 2017.

[8] Zeide E. Artificial Intelligence in Higher Education: Applications,

[9] Dogson M., Gann M. Artificial intelligence will transform universities.

[10] Mims C. AI Isn't Magical and Won't Help You Reopen Your Business. Promise and Perils, and Ethical Questions. August 26, 2019. WSJ, May, 30, 2020. 
DOI: $10.17747 /$ TEDS-2020-22-27

Mikhail V. Zharikov

World Finance Department

Financial University under the Government of the Russian Federation

Moscow, Russia michaelzharikoff@gmail.com

\title{
THE MODEL OF THE BRICS' SHARED INTEREST RATE TO CIRCULATE A DIGITAL CURRENCY
}

\begin{abstract}
The purpose is to offer an approach to introducing a market interest rate to circulate a digital currency in the BRICS. The topic is time-relevant, since economics today faces difficult challenges posed by questions about price stability, future growth and money market equilibrium. A digital currency is a special issue today due to the outbreak of covid-19, which made many central banks think about contactless means of payment. The author revealed policy tools to circulate a hypothetical digital currency in the BRICS, needed for the pentalateral use. The theoretical significance is to lay the foundation for a model that can be used to set up a virtual regional money market for the BRICS. In practical terms the article recommends a set of policy decisions to overcome the coronavirus crisis of 2020.
\end{abstract}

Keywords - BRICS; digital currency; virtual money market; shared interest rate; liberal and gradualist approaches; credit surplus; digital money revenue

\section{INTRODUCTION}

The BRICS celebrates its 20th anniversary in 2021. It is clear by now that unlike the European Union or Eurasian Economic Union, the BRICS is not an integration agreement [1]. The integration process of the BRICS is quite difficult to accomplish due to territorial, cultural, political and economic differences of the member states. However, in the past two decades we can find a few multilateral efforts on part of the member states aimed at deeper trade and cooperation [2].

Things got even more difficult after the outbreak of covid19 in 2020. The coronavirus crisis which followed became a sort of a litmus paper to test the penta-lateral cooperation within the BRICS. The hope is that the BRICS will get out of the crisis stronger. A new period of the BRICS cooperation will bring potential benefits and opportunities for the member states as well as for the countries in close proximity. One of those opportunities may well become the digitization of the trade settlement deals in the BRICS and related countries of the region to bypass the US dollar [3].

In this respect, this paper has a purpose to explain the need to create a model of a shared interest rate of the BRICS as a regional mechanism to finance multilateral development with an optimal cost of capital for the countries of the region.

To meet their needs in new loans for development on better terms compared to the international financial institutions, such as the IMF and the World Bank, the BRICS and the countries of the region can potentially create a virtual regional multilateral money market with an equilibrium interest rate [4].

\section{METHODS}

The optimal equilibrium interest rate can be determined on the conventional idea based on the money supply and the demand for money for the members of the BRICS and other countries of the region. Graphically, this can be expressed in a chart displaying two curves representing the money supply and the demand for money on the shared money market of the BRICS that may emerge in the future. The underlying research proposes a ten-year plan to achieve that by 2030 if all goes well. This market may simultaneously become the market for a new digital currency of the BRICS. As is well-known, the curves of the supply and demand intersect at a point that demonstrates the level of an interest rate at which the central bank acquires IOUs. In central bank operations, there are shortterm, mid-term and long-term rates, generally known as the rates of refinancing. According 
to the neoclassic economics, the graph of supply of and demand for some good, including money, is to do with the curves only in the short term. Therefore, this paper attempts to build the shortterm shared interest rate for the BRICS and other countries of the region.

To simplify the model, which is being constructed here, the research supposes that the supply of money on the potential virtual multilateral market of the BRICS digital currency in the short run must take shape of a vertical line. This is motivated by the fact that the supply of money can potentially be absolutely inelastic and be determined depending on the character of a shared or consensual monetary policy. In turn, the demand for money will intersect with the curve of money supply at a point which will reflect the shared interest rate for the BRICS. This rate will be higher in comparison with the rate of the People's Bank of China at whose expense the supply of money is supposed to be provided as this paper recommends.

\section{DISCUSSION}

Since the countries with the world reserve currencies usually pursue loose monetary policy [5], a central monetary authority of the BRICS will also have to do that. The central monetary authority will have to expand the money supply of the BRICS digital currency in case of an increase in the demand for it on the hypothetical virtual money market. As a result, the local inter-bank offer rates in the high-interest-rate members of the BRICS will decrease, and the money supply and the demand for the digital currency will be set at a new equilibrium level which will be optimal for them [6].

Once the shared interest rate is established on the BRICS hypothetical virtual money market, the member states of the BRICS will be faced with a problem of having to adjust their local rates of refinancing. According to the hypothesis introduced in the research, Brazil will have to do with the biggest drop in its local rate of refinancing, because in 2016-2019 there was the highest rate of refinancing in the BRICS there. In case of China, the rate of refinancing is going to be set at a level a bit higher compared to the domestic rate in China.

\section{A. THE LIBERAL MODEL OF THE SHARED INTEREST RATE FOR THE BRICS}

The liberal model of price building was originally supposed to be used for the world market of goods such as grain, crude oil, natural gas, etc. These commodities are usually traded at world prices. This paper proposes that this model be used also to determine the shared interest rate for the BRICS. This is done because generally an interest rate is the price of money at which commercial banks get loans from a central bank. This model is applicable for the purpose, since it poses no constraints for cross-border transactions. And since the world money market is a virtual place which works in total absence of any barriers, the liberal model is going to be the optimal mechanism to set up the shared interest rate for the BRICS [7].

The curves of domestic supply and demand for the hypothetical digital currency of the BRICS are formed depending on the loan rates of the major commercial banks and local supply of money which were used to determine the level of the shared interest rate. To simplify the model of the shared interest rate for the BRICS, a trend line should be drawn which flattens the deviations of the loan rates set by individual commercial banks. The equations of trend lines for each member state of the BRICS are found in Table 1. In the BRICS the money demand curve is least elastic in Brazil, and it is most elastic in China. In turn, India and South Africa have elasticities of demand for money a bit larger than in Russia. 
TABLE I. DIGITAL MONEY DEMAND CURVE EQUATIONS IN THE BRICS

\begin{tabular}{|l|l|}
\hline \multicolumn{1}{|c|}{ BRICS } & \multicolumn{1}{c|}{ The equations of digital money demand } \\
\hline Brazil & $\mathrm{y}=-0,26174 \mathrm{x}+31,17764$ \\
\hline Russia & $\mathrm{y}=-0,09324 \mathrm{x}+21,74156$ \\
\hline India & $\mathrm{y}=-0,04007 \mathrm{x}+11,42709$ \\
\hline China & $\mathrm{y}=-0,000891266 \mathrm{x}+3,905214846$ \\
\hline South Africa & $\mathrm{y}=-0,77467 \mathrm{x}+14,85721$ \\
\hline BRICS & $\mathrm{y}=-1,9115 \mathrm{x}+12,47$ \\
\hline
\end{tabular}

Source: author's calculations based on the official financial statements of commercial banks from the BRICS.

\section{B. THE GRADUALIST MODEL OF THE SHARED INTEREST RATE FOR THE BRICS}

Since the liberal model of the shared interest rate for the BRICS implies no constraints, the loans provided through the described mechanism ought to be consumed in one year's time. It means that Brazil, Russia, India and South Africa are to consume virtually all credit provided by China at the moment the loans are granted. Such quick consumption of loaned money in Greece, for example, when the euro had first been introduced, led to the outbreak of the debt crisis in the country and later to a technical default [8].

Contrary to that, if the shared interest rate for the BRICS were to be set up step-by-step, over several years according to the gradualist approach, it would have reached the level of rR2, or $2 \%$, in correspondence with the model built, and the respective volumes of additional external loans provided by China would have increased to 44.7 billion dollars in Brazil,

83.7 billion dollars in Russia, 118.1 billion dollars in India and

6.4 billion dollars in South Africa (Fig. 1).

Fig. 1. Gradualist model of the shared interest for the BRICS

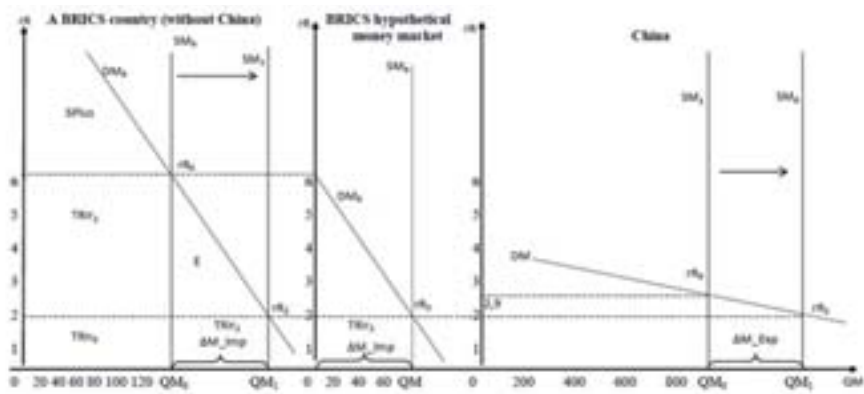

These volumes contrary to the liberal model would have then been allocated relatively evenly over the entire period of monetary and financial harmonization of the BRICS, which would have been less painful for them, and this would have allowed them to gradually adapt to the transformation of the national monetary systems and their consequent joining the common monetary system. At the same time, the credit surpluses in each of the BRICS would have also increased gradually: in Brazil - by 16.9 billion dollars, in Russia - by 21 billion dollars, in India - by 13.9 billion dollars and South Africa - by 1.1 billion dollars, without causing consumer boom, although these volumes would have exceeded the credit surpluses received by Brazil, Russia, India and South Africa as a result of forced liberalization. 
The cumulative loans provided to Brazil, Russia, India and South Africa according to the gradualist model built would have amounted to 253 billion dollars by 2030 , which also just like in case of the liberal model would have significantly exceeded the capacity of the BRICS Development Bank.

A next stage of the calculations is supposed to determine the cumulative volume of loans provided at the shared interest rate for the BRICS as a single entity. The initial hypothesis about the shared money market for the BRICS and the shared interest rate supposed that its level could have settled at a level, unfavorable for China and significantly higher than the initial rate. However, the resulting shared interest rate for the BRICS distinguishes from the initial equilibrium of the national monetary system in China by only $0.05 \%$. Nevertheless, the increase in the local loan rate in China by this small amount, according to the model built, would have led to a decrease in the quantity of money in that country's economy circulation by 55.3 billion dollars.

In turn, the money loaned out at the new shared rate of interest for the BRICS as a single entity at $2 \%$ in accordance with the gradualist model is going to have a deeper impact on the respective national economies than as a result of decreasing domestic rates at the initial stage of the calculations, i.e. based on the liberal model. Thus, in addition to the initial supply of money loaned, the money in circulation would have increased to 111.2 billion dollars in Brazil, 209.7 billion dollars in Russia, 234.9 billion dollars in India and 16.6 billion dollars in South Africa without the printing presses. The cumulative influx of the money loaned out to these four countries would have been equal to 253 billion dollars.

The outflow of capital from China at the $2 \%$ interest rate would have exceeded 1 trillion dollars. It means China could in fact have generated additional money supply for other countries of the region to the amount of almost 772 billion dollars loaned out in the new shared digital currency of the BRICS. Thus, the equilibrium of the monetary system of the BRICS based on the liberal model of the shared interest rate could have been achieved by injecting 217 billion dollars. The gradualist model could have done that by injecting 253 billion dollars. Hence, the resulting equilibrium differs from the initial one in the liberal model by almost 40 billion dollars.

The liberal and gradualist models built by the author to determine the shared interest rate exhibit the hypothetical money market equilibrium, namely the amount of credit exported from China must equal to the amount of capital received by Brazil, Russia, India and South Africa, i.e. the influx of capital to Brazil, Russia, India and South Africa and the outflow of capital from China are one and the same figure. Alongside this, when the needs of Brazil, Russia, India and South Africa in loans exceed their initial capacity, China would have to create additional supply of money expressed in the new digital currency at the shared interest rate both for the hypothetical money market and for other countries' purposes.

If there were no equilibrium, this would have meant an error in the model built. The point is that if in the course of calculating loan rates for Brazil, Russia, India and South Africa it turned out that more loans could be provided at them in Brazil than in India, for example, although according to the law of demand it must be vice versa since the demand elasticity for money in the latter were bigger than in the former, then it might be caused by a statistical error in the calculations conducted. Therefore, since the loan rate is determined for each of the BRICS on an individual basis with regard to the potential needs in loans and the capacity of a country to efficiently absorb them with no implications such as high inflation, it is necessary to introduce respective adjustments to the model built.

First of all, the liberal model of the shared interest rate for the BRICS did take into account that on the hypothetical shared money market the curves of supply and demand might alter their elasticity. At this point the rate itself might not change, but what was necessarily going to change was the quantity of money provided as loans. It must either increase or decrease. If this is true, it is critical to step back to the stage of determining the rates and the volume of new digital money supply on the charts representing Brazil, Russia, India and South Africa and make adjustments for 
the amount of money supplied, this time taking into consideration a principle according to which the higher the shared interest rate, the less is the amount of credit and vice versa.

Secondly, since the shared interest rate is formed on the hypothetical digital money of the BRICS, it is important to exclude a possibility of an error in the amount of the interest rate in general since the use of the same equations in each of the cases is going to produce a universal system of functions, and it will end in the universal methodology and a common approach to carrying out the calculations. As to the possibility of an arithmetic error, the model still stays true even at this point, because the amount of loans made in the economy is directly dependent on its capacity to wholly and efficiently absorb the money loaned out. Oversupply of loans, in turn, may lead to hypertrophied expenditure by households, manufacturing firms and the economy at large. It may also cause a credit boom, overheat and an eventual sharp recession.

But since the liberal model was initially used to set the rates, it supposes no restrictions. Therefore, the amount of money loaned out cannot be constrained by anything. Hence, the demand for loans on part of the BRICS at the shared interest rate does not change. What changes is the amount of loans made at that rate. Hence, it is important to adjust the elasticity of the respective curves. As a result of referring the new curve of the demand for loans to the curve of money supply on the shared market of the BRICS, there emerges the required shared rate of refinancing for the BRICS as a single entity.

\section{RESULTS}

A final stage of building the model of the shared interest rate for the BRICS is to estimate the implications of introducing the new rate for the banking sectors of the BRICS. Achieving such a result could be especially significant, for the member states of the BRICS when looking for ways aimed at helping economic recovery after the coronavirus crisis of 2020.

Based on the research, the following outcomes can be delivered:

- The article offers a very cautious gradualist approach in dealing with a hypothetical digital currency for the BRICS, based on a virtual platform that can be used by the countries of the related region.

- The system of digital money circulation in the economies of the region is not perfect. However, it continually improves and, most importantly, in the region today there is no more effectively working alternative than the monetary system based on a digital currency.

- The international division of labor, the internationalization of capital, production and labor exist only if there is highly developed money circulation. The modern architecture of money circulation and money itself gave birth to a human being of today and the organization of human labor on a highly intellectual level. In the end, technological change and industrial revolution would be impossible without such trade and dealings in digital money, cryptocurrencies and other quasi money.

- Since the overwhelming majority of assets in the world are expressed in US dollars, the introduction of the new digital currency for the BRICS and other countries of the region will hardly influence the world market.

- The research revealed the significance of the most important macroeconomic indicators which characterize the hypothetical digital money market of the BRICS, namely, a shared interest rate and the quantity of digital money in circulation needed for the penta-lateral use as well as for the use of the countries in close proximity.

\section{ACKNOWLEDGMENT}

The article was written with financial support of the Russian federal budget according to the assignment given to the Financial University. 


\section{REFERENCES}

[1] R. Beetsma, M. Giuliodori, F. De Jong, and D. Widijanto, "Price effects of sovereign debt auctions in the euro-zone: the role of the crisis," Journal of Financial Intermediation, no 25, pp. 30-53, 2016.

[2] D. Boddin, and F. Stähler, "The organization of international trade," CESifo Working Paper, no. 7378, pp. 6-10, 2018.

[3] Y.(G.) Hou, and S. Li, "Volatility and skewness spillover between stock index and stock index futures markets during a crash period: new evidence from China," International Review of Economics \& Finance, vol. 3, no. 66, pp. 166-188, 2020. DOI: 10.1016/j. iref.2019.11.003

[4] T. Jain, S. Sehgal, and R. Agrawal, "Disruptive innovations, fundamental strength and stock winners: implications for stock index revisions," Vision-The Journal of Business Perspective, vol. 3, no. 24, pp. 356-370, 2020. DOI: 10.1177/0972262920928890

[5] K. Khan, H.W. Zhao, H. Zhang, H.L. Yang, M. Haroon, and A. Jahanger, "The impact of covid-19 pandemic on stock markets: an empirical analysis of world major stock indices," Journal of Asian Finance Economics and Business, vol. 7, no. 7, pp. 463-474, 2020. DOI: 10.13106/jafeb.2020.vol7.no7.463

[6] A.A. Salisu, and L.O. Akanni, "Constructing a global fear index for the covid-19 pandemic," Emerging Markets Finance and Trade, vol. 10, no. 56, pp. 2310-2331, 2020. DOI: 10.1080/1540496X.2020.1785424

[7] M. Younsi, and M. Bechtini, "Economic growth, financial development, and income inequality in BRICS countries: does Kuznets' inverted ushaped curve exist?" Journal of the Knowledge Economy, vol. 2, no. 11, pp. 721-742, 2020. DOI 10.1007/s13132-018-0569-2

[8] P. Zou, Q. Wang, J.H. Xie, and C.X. Zhou, "Does doing good lead to doing better in emerging markets? Stock market responses to the SRI index announcements in Brazil, China, and South Africa," Journal of the Academy of Marketing Science, vol. 5, no. 48, pp. 966-986, 2020. DOI: 10.1007/s11747-019-00651-z 
DOI: 10.17747/TEDS-2020-28-32

Svetlana V. Karpova ${ }^{1}$, Olga E. Ustinova ${ }^{2}$

1Professor of the Logistics and Marketing Department, 2Department of Management Financial University under the Government of the Russian Federation Moscow, Russia

${ }^{1}$ SVKarpova@fa.ru, ${ }^{2}$ OEUstinova@fa

\title{
TRANSFORMATION OF CONSUMER BEHAVIOR IN THE INDUSTRIAL MARKET IN THE CONTEXT OF DIGITALIZATION
}

\begin{abstract}
Intense competition in industrial markets leads to constant changes in consumer behavior. Difficult pricing negotiations and abuse of power make it difficult for participants to interact in sales management. Taking these facts into account, it should be noted that for the sales manager, price becomes an indicator of success in the end result of negotiations. At the same time, surveys of heads of sales departments in the industrial sector show that, among other important elements of negotiations, are the duration of the business relationship, the reputation of the supplier. Despite these tendencies, questions remain about other factors that can consciously or unconsciously influence the negotiation situation, both in a positive and negative direction. The research results were carried out in accordance with the order of the Financial University under the Government of the Russian Federation of March 20, 2020 No. 0564 / o "On the organization of the implementation of the second stage of fundamental research works carried out within the framework of the state assignment in 2020." on the topic "Theory of consumer behavior in the modern economy".
\end{abstract}

Keywords - marketing technologies, procurement, industrial market, consumer behavior, online commerce, formalized interviews, innovative products

\section{INTRODUCTION}

Changes in the socio-economic life of the country have given rise to significant changes in the consumption of manufacturing companies. Saturation of the market with industrial goods provides the possibility of variable satisfaction of needs and an increase in the requirements of various categories of consumers of industrial goods for product quality. The release of products designed for the average level of requirements has become economically unprofitable. In such conditions, the main task of manufacturing companies is to develop products with predetermined standards of consumer properties that best meet the structure of the needs of the target market for industrial goods. Achieving this goal involves establishing feedback channels with consumers and their inclusion in the product quality management system.

\section{LITERATURE REVIEW}

Despite the fact that several decades have passed, in the analysis of industrial business relations, the concepts of the procurement center are actively cited $[8,2,1]$. The conditional grouping of business representatives who participate in making a purchase decision is still associated with functions and organizational distribution [6]. Decision-makers are players who have defined behavioral expectations in the procurement process and who must meet those expectations in more or less strong behavioral patterns (role behavior) [1]. Typical examples are "cost-oriented buyer" or "technology-preferred development project manager". In the context of dynamic development and the international influence of the industrial environment, this classic role-playing concept becomes insufficient. For example, company representatives involved in the procurement process should define organizational functions. In an industrial environment, they often behave differently from what their role is usually understood to be. The traditional approach to the procurement center does not take into account important institutional and individual influencing factors [3]. 
In Germany, Austria and Switzerland, the Sinus-Milieu system, developed by the Sinus Sociovision in Heidelberg, is the most common typology of lifestyles [4]. It classifies target groups according to a detailed analysis of social worlds. The basic idea is that people with the same characteristics, such as age, gender, job, or income, can be categorized into different target groups. Formal similarities or identical social status can be accompanied by completely different views and values. The expectations and buying behavior of these consumers can only be methodically compiled through a holistic analysis of their lifestyles and attitudes [4]. By the late 1970s, Sinus Sociovision presented its results for the first time through quality interviews related to the daily lives of consumers. The indicators of this system classify people according to sociocultural aspects, such as established or modern performer, positioning them according to their lifestyle, i.e. value system and social status.

The limited behavioral relevance in targeting "sociodemographic twins" in the consumer goods sector can be transferred to the identical roles of a single purchasing center function in the industrial goods environment. No two purchasing managers are the same. This means that the shopping center twins can vary greatly in their shopping behavior. Therefore, M. Kuhn and Y. Zajontz [7] carried out micro-segmentation to characterize the different individuals involved in procurement and go beyond the purely structural and functional orientation of the procurement center. The authors divided these so-called industrial lifestyle types into group workshops in which young professionals or trainees from more than 50 industrial companies were invited to share their experience in sales and procurement to define industrial lifestyle types. In addition to functional and hierarchical aspects, typical value principles and characteristics that affect personality were used as segmentation features.

In addition to the different types of industrial lifestyles, other aspects such as the quality and price of the service are important in making industrial purchasing decisions [3]. The duration of the business relationship also influences the buying behavior, as the advantage of the negotiation outcome decreases as the length of the negotiation increases [9].

The use of digital and cloud technologies, on the one hand, led to the growth of the online trading market, on the other hand, they leveled the conditions for all companies, including large, medium and small [5]. Thus, the traditional barriers that prevented small firms from entering global markets have disappeared. This has a corresponding impact on branding processes and the entire trademark ecosystem.

\section{METHODS}

The effective functioning of companies in modern conditions requires a deep analysis of the developments in the market and phenomena. At the stage of searching for the research methodology, the choice was made in favor of interviews. When preparing and conducting research, a methodological apparatus was used that ensures the reliability of scientific results and the reliability of the data obtained. The objects of the research were organizations of large, medium and small businesses. The subject of the research is the behavior of industrial market participants in the procurement process. The aim of the study was to identify the features of consumer behavior in industrial markets in the context of digital transformation.

Based on the use of a qualitative approach, the study determined a sample set of formalized interviews in the amount of 30 respondents, represented by company leaders and managers who procure goods and services. At the same time, the method of forming equal quotas was used: 10 respondents for each type of business, depending on the size of the company. The collection of tools was realized through modern digital technologies (google-forms). In the structure of the respondents, $60.0 \%$ have been working in this position for no more than 10 years, $26.7 \%$ have a similar work experience in the range of 11-20 years and have been purchasing in the industrial market for more than 20 years, $13.3 \%$ of the respondents. At the same time, $96.7 \%$ of interviewers have higher education including an academic degree. 
The systematization and processing of the bulk of the responses received was carried out in accordance with the requirements of ensuring the reliability of sociological and marketing information by summarizing it in a summary table and further highlighting the characteristics of the behavior of participants in the industrial market when making purchases. This allowed the results of the study to be evaluated against standard procedures to ensure the representativeness of the study sample, application and data entry.

\section{DISCUSSION AND RESULTS}

Identifying, examining and selecting a supplier are important elements of procurement. This process may involve a single supplier, several employees, a special process managed by a supervisor. Procurement professionals take different approaches to organizing their work. This is influenced by education received, current age of work, character, willingness to take risks, etc.

Analysis of respondents' answers showed that when using supplier selection solutions, representatives of small businesses rely on situational analysis, management opinions, as well as recommendations and opinions of employees. Mid-sized companies also work with partners with whom they have been working for a long time. Decisions are usually made centrally based on careful analysis of software usage. Large business makes a choice based on "the recommendations of customers, their own experience with suppliers, their reputation." As a rule, the choice of the perfect one on the basis of careful analysis is centralized through the relevant departments. Among the criteria of importance in making purchases, representatives of small businesses rate their own work experience lower (13\%) and give preference, first of all, to the functional characteristics of products, quality assurance and a favorable price offer.

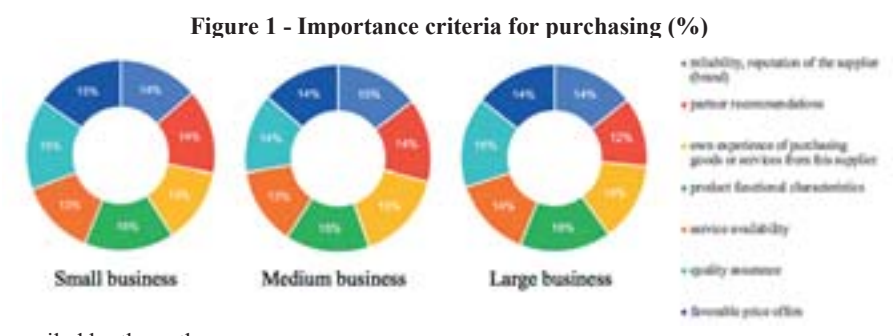

Source: compiled by the authors

On the contrary, medium-sized businesses most of all trust their own experience of purchasing from a specific supplier (15\%) and least of all the availability of service (13\%). For large companies, performance and quality assurance, reliability and supplier reputation are of highest value. Least of all big business trusts recommendations of partners.

In today's highly competitive environment, the ability of companies to create and introduce new products to ensure technological leadership is becoming increasingly important. Since, when purchasing innovative products, companies may not have sufficient information about them, this process, as a rule, involves several sequential stages. At the first stage, the customer company assesses the supplier's reputation, his experience in the execution of similar contracts, clarifies information about the product, etc. At the second stage, technical and commercial requirements are clarified, taking into account alternative proposals from other suppliers. It is important to emphasize that multi-stage procurement procedures for innovative products are provided for by the legislation of different countries. Within the framework of the study, the opinions of managers regarding their preferences in terms of product innovation were not significantly divided. Thus, small and medium-sized businesses mainly rely on wellknown and market-tested products. Large business makes certain requirements for it "the product must meet the technical requirements of the internal customer", sometimes purchasing managers give preference to new innovative products. 
Among the main characteristics of innovative products that affect the reaction of consumers in the industrial market, the following are known:

- the advantage, features or the degree of perception of the new product as the best available analogue;

- compatibility or relevance of the new product with the

- values and practical experience of the manager; complexity as the level of accessibility of the employee's perception of a new product and its use, including technical complexity, fear of rapid moral and physical aging, social reaction; availability of the possibility of trial use of products.

Thus, one of the main features of the procurement of innovative products can be attributed to the lack of clearly established technical characteristics and significant R\&D expenditures, in contrast to known products.

The digitalization of business processes puts forward new requirements for the organization of communication between participants in the industrial market. Thanks to modern technology, it has become possible to create a portfolio of data containing detailed information about the consumer. Thus, both in production and in advertising, it became possible to combine mass production of products and an individual approach to the consumer and his choice. A new ideology has emerged, based on the customer's internal motivation.

The study showed that the parameters of newsletters presented in Figure 2 are important for consumer activity. For respondents of small and medium-sized businesses, the timeliness of information about promotions and discounts, as well as the ability to request additional information, have the highest value on a 5-point scale.

Figure 2 - Parameters of informational advertising mailings Source: compiled by the authors

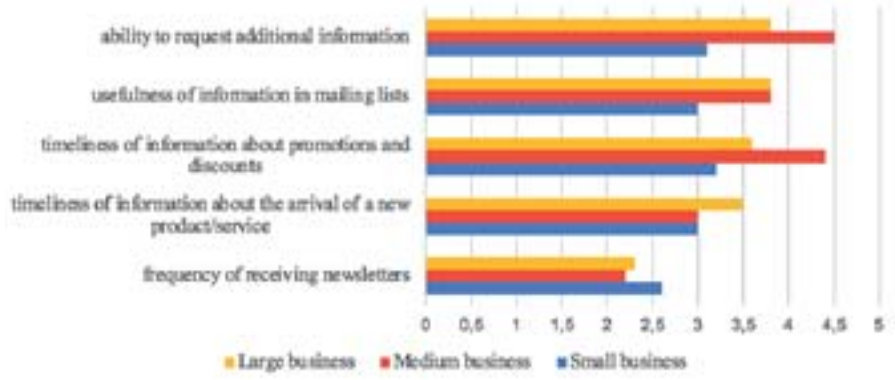

The least importance is attached to the timeliness of information about the arrival of a new product / service. For large companies, important parameters include the usefulness of information in mailings and the ability to query queries. It should be noted that all companies rated the newsletter frequency parameter low. A distinctive feature of the industrial market is the limited number of customers. In this regard, it becomes important to build communications with customers. Digital marketing is proving to be effective with both consumers and businesses. At the same time, it is important to find out what is interesting to consumers of the industrial market, what inspires them or what worries them.

\section{CONCLUTION}

In the digital economy, the study of the characteristics of consumer behavior should help to improve the efficiency of not only procurement, but also the entire financial and economic activities of the company and, as a result, increase its competitiveness. In general, the theory of consumer behavior in industrial markets is developing and enriching under the influence of global civilization 
processes, characterized by the active spread of innovations, advanced digital and production technologies, and the expansion of the geography of customers and suppliers. One of the most significant trends in the transformation of consumer behavior and segmentation is the distribution channels used, based on the active promotion and use of digital technologies.

\section{REFERENCES}

[1] Backhaus, K., \& Voeth, M. (2010). Industriegütermarketing. Munich: Vahlen.

[2] Hutt, M. D., \& Speh, T. W. (2004). Business marketing management: A strategic view of industrial and organizational markets. London: Thomson.

[3] Homburg, C. (2012). Marketingmanagement: Strategie - Instrumente - Umsetzung Unternehmensführung. Heidelberg: Gabler.

[4] Kalka, J., \& Allgayer, F. (2006). Zielgruppen —wie sie leben, was sie kaufen, woran sie glauben. Moderne Industrie: Landsberg am Lech.

[5] Karpova S.V., Ustinova O.E. (2019). Brend kak instrument marketinga: vliyanie na povedenie potrebitelej. Risk: resursy, informaciya, snabzhenie, konkurenciya. (4). 68-73. (in Russian).

[6] Kennedy, A. (1982). Industrial buying behaviour: A review of literature and research needs. Management Decision, 20, 38-51.

[7] Kuhn, M., \& Zajontz, Y. (2011). Industrielles Marketing. Munich: Oldenbourg.

[8] Roth, S. (2006). Preismanagement für Leistungsbündel. Wiesbaden: Deutscher Universitätsverlag.

[9] Webster, F. E. J., \& Wind, Y. (1972). Organizational buying behavior. Englewood Cliffs, NJ: Prentice Hall. 
DOI: 10.17747/TEDS-2020-33-35

Natalia Lvovna Smith ${ }^{1}$, Anton Vladimirovich Antonov ${ }^{1}$

${ }^{1}$ Department of Management, Financial University under the Government of the Russian Federation

Moscow, Russia

NLSmit@fa.ru, avantonov@fa.ru

\title{
DETERMINING THE DEGREE OF CULTURAL DISTANCE IN DIVERSITY MANAGEMENT
}

The article was prepared based on the results of research carried out at the expense of budgetary funds on the state order of the Financial University, within the framework of applied research work GZ-PI40-20 on the topic "Development of methods and mechanisms for intercultural adaptation of foreign students" determining the degree of cultural distance in diversity management.

\begin{abstract}
In the process of transforming the priority of material and technical values to the paradigm of flexible thinking, communicative interaction becomes a new value, which is a vital competence in the integrative multicultural reality of the global world, where cultural diversity is recognized as a key value. Diversity management is now dominant in organizational management, the ability to focus on organizing behavior based on the interaction of all parties in an environment where many cultures are intertwined. The multidimensionality of the multicultural environment poses a challenge in determining the degree of cultural distance in an organization. This allows us to understand the similarities and differences between the host culture and the culture of foreign visitors and students, and to identify gaps and barriers to intercultural interaction and adaptation tools. It also calls for the formation of all actors in the educational process of the necessary knowledge and skills that contribute to their adequate orientation in belonging to their own culture and awareness of the influence of their value dominants in practical situations of intercultural communication. Thus, in organizational management, host Russian universities face the challenge of recognizing their own cultural paradigm and thinking.
\end{abstract}

Keywords - diversity management, soft skills, cultural intelligence, communicative competence, paradigm of thinking, intercultural interaction, cultural adaptation

In the context of the integration of Russian universities into global education, it becomes more and more important to develop the competencies of intercultural interaction among all actors of the educational process. [1]

In the process of transformation of the material and technical values of the industrial society, the instrumental mind [2] the last century is replaced by the paradigm of flexible thinking [3]

In the process of developing internationalization, the environment of universities is constantly changing, this affects all its levels: social, informational, academic. The multidimensionality of the multicultural environment challenges educational organizations to determine the degree of cultural distance in an organization. This allows us to understand the similarities and differences between the host culture and the culture of foreign visitors and learners and to identify gaps and barriers to intercultural interaction and adaptation tools.

The ability to overcome various kinds of barriers (linguistic, psychological, sociobehavioral and others) in the process of intercultural communication is determined by the degree of differences between the subjects of interaction, which cannot be eliminated immediately in the communication process and, due to their practical significance, require special efforts and special knowledge to overcome [4]. 


\section{TYPES OF CULTURES IDENTIFIED}

Cultures can be viewed in a geographical, historical context, grouping them into different clusters [5]. In addition, according to the conclusions of G. Triandis, cultures influence selfperceptions along an independent (individualistic) and interdependent (collectivist) continuum [6].

In independent cultures, individuals can reinforce their self-image because self-sufficiency is emphasized as an individual agent [7]. People in Western cultures tend to see themselves on a fundamental level as separate and distinct from others, in the same way they perceive representatives of other cultures and expect similar identification and similar behavior from them.

Representatives of collectivist cultures demand from their carriers such a fusion with the group, in which it could be a single whole and effectively protect its members; they are more concerned with how they can benefit their social group and expect the same values from representatives of other cultures.

\section{DOMESTIC PERSPECTIVE}

This dichotomy in expectations leads to misunderstandings in the communication process. According to the study of Dervish and Gunther [8], representatives of other cultures reach mutual understanding with bearers of individualist cultures more easily than with those of collectivist ones. Individualist cultures welcome independence, they are more focused on success, selfpromotion and self-improvement [9], so representatives of such cultures are accustomed to doing as they see fit, even if their position does not coincide with the position of the group as a whole. In this regard, representatives of American, Anglo-Saxon cultures, which are typically individualistic, experience the least amount of difficulties in communicating with strangers and with foreigners, and representatives of collectivist cultures - Japanese and Koreans and representatives of other Asian cultural clusters - experience the greatest difficulties in communication and adaptation. It is important to note that for all the cultural complexity [10], in general, Russian culture largely gravitates towards the collectivist type, which means that the majority of representatives of this culture tend not to build an intercultural dialogue, but to dominate with the values of Russian culture when interacting with newcomers from abroad and representatives of other cultures. Thus, in organizational management, host Russian universities face the challenge of realizing their own cultural paradigm and paradigm of thinking.

Organizations living "within the paradigm of their own corporate culture" find it very difficult to comprehend and structure its content. In order "to understand what the sea is, the fish must see the land." Understanding and awareness of one's own paradigm can become the basis for further regulation of the issues of overcoming intercultural barriers and methods of managing diversity in the donor organization, the recipient of the subject of communication.

\section{CONCLUSION}

In this regard, it is necessary to outline the following transformations in the organizational culture of the host Russian side:

- Appeal to the knowledge of the participants about the presence of cultural differences and the possibility of their manifestation in the process of communication. In this regard, in such situations, it is required that the communication participants first of all positively perceive the very existence of barriers as such, that their overcoming is the norm of intercultural communication, and not a denial of the otherness of the interlocutor.

- Development of cultural literacy, emotional intelligence and intercultural competencies. This involves targeted training in flexible skills of all subjects of communication at all levels of the organization, both in educational and service terms. Particularly important is the systematic and regular work on the soft adaptation of foreign visitors, students, expats to the Russian cultural environment, taking into account their belonging to various cultural clusters, individualist and collectivist groups. 
- Purposeful use of cultural diversity in the educational process to ensure a greater degree of inclusiveness and as a learning resource that allows integrating the experience and knowledge of not only foreign students, but also students from different regions of the country, from different subcultural groups and social strata of society

- Formation of the necessary knowledge and skills in all actors of the educational process in order to recognize their own mental models contributing to their adequate orientation in belonging to their own culture and awareness of the influence of their value dominants in practical situations of intercultural communication. The existing knowledge in this case acquires a personal meaning, since their bearer develops a personal existential position.

- When developing a strategy for attracting and involving foreign students in the sociocultural environment of Russian universities, focus on soft power technologies and creating an enabling environment that, on the one hand, convey the values of diversity and tolerance and, on the other hand, the values of high quality and attractiveness of Russian education.

\section{REFERENCES}

[1] Prikhodko L.V., Smith N.L., Ilkevich S.V. leadership and management of change in the adaptive environment of european and russian universities p. 224 Management sciences in the modern world: corp. report scientific-practical Conf. FU .; scientific. review. magazine "Strategic decisions and risk management". 2019. - 710 s..

[2] Orekhovskaya N.A. Intercultural communication training: methodological basis and tools. // Political processes and practices. M. 2019 p. 137.

[3] Barker, J. Paradigms: The Business of Discovering the Future. Transl. from English. Moscow; 2007. 187 p.

[4] Bobrova S.P., Smirnova E.L. Fundamentals of communication theory / Textbook. allowance. - Ivanovo: Ivan. state un-t, 2005.

[5] Ten, Yu.P. (2006). Symbol in intercultural communication. Proceedings of higher educational institutions. North Caucasian region. Social Sciences, (2).

[6] Triandis, H. C. (1989). The self and social behavior in differing cultural contexts. Psychological Review, 96(3), 506-520.

[7] Heine, S. J., Lehman, D. R., Markus, H. R., \& Kitayama, S. (1999). Is there a universal need for positive self-regard?. Psychological review, 106(4), 766

[8] Darwish, Dr. Abdel Fattah \& Huber, Gunter. (2003). Individualism vs. Collectivism in Different Cultures: A cross-cultural study. Intercultural Education, 14. 47-56 ( USA). 10.1080/1467598032000044647

[9] Heine, S. J., \& Lehman, D. R. (1999). Culture, self-discrepancies, and self-satisfaction. Personality and Social Psychology Bulletin, 25, 915-925.

[10] Lebedeva N.M. An introduction to ethnic and cross-cultural psychology. - M .: Klyuch + S, 1999.S. 45. 
DOI: $10.17747 /$ TEDS-2020-36-39

Biruta Svagzdiene ${ }^{1}$, Edmundas Jasinskas, Arturas Simanavicius

Department of Sports and Tourism Management

Lithuanian Sports University

Sporto st.6, Kaunas, Lithuania

'biruta.svagzdiene@1su.lt

\title{
A STRATEGIC FRAMEWORK FOR A LEISURE SERVICES BUSINESS MODEL IN THE SHARING ECONOMY
}

\begin{abstract}
The sharing economy is an attractive alternative for consumers due to its economic benefits (low costs), which was seen as an important practice after the global economic crisis the growing business model presents opportunities and challenges for leisure and hospitality businesses and tourist destinations.
\end{abstract}

Keywords - framewirk; leisure, business; economy; consumer.

\section{INTRODUCTION}

The growing business model presents opportunities and challenges for leisure and hospitality businesses and tourist destinations. According to a study conducted by HR\&amp; A Advisors [1], travelers who used Airbnb spent a total of \$56 million in one year in San Francisco, California and earned income that is critical to local residents. On the other hand, the emergence of such businesses also raises the critical question of whether it creates a new market in the leisure industry or replaces the existing one (i.e. serves as a substitute for the established sector). In addition, it is also important to assess the longevity of such a business model in the light of the ever-changing business environment in hospitality. In order to provide answers to this question of the study, it is important to identify the motivational factors that encourage or hinder travelers' involvement in general consumption and to assess the potential impact of this business model in creating a new leisure and hospitality market.

The problem is: What are the challenges for the leisure industry in the sharing economy and what are the opportunities for the sharing economy when assessing the leisure sector?

The subject of the study is the impact of the sharing economy on the leisure sector.

The aim of the study is to analyze the phenomenon, opportunities and challenges of the sharing economy and to describe the impact of the sharing economy on leisure sectors

\section{SHARING THE ECONOMY AS A PHENOMENONS}

The sharing economy arose even before the urbanization period. When agriculture was the main source of income, sharing and general consumption were a simple and natural part of life, because people lived their whole lives in the same villages, so the sense of communion was incredibly strong [2].

Over time, technology has allowed people to move further out of their home and seek better livelihoods in cities. The process of urbanization has made people more independent and isolated, which has reduced the communality and sense of belonging of that time [2] It is therefore argued that exchange, trade and self-employment are not novelty, and digital technologies have simply returned to communities that have flourished in the past [3]. Global economic downturn of 2008 played a role in the creation of a modern sharing economy; when the value of costs was low, new business measures were developed. In addition, increased environmental concerns have led to success in sharing economic products and services [4]

Scientists say the sharing economy was first developed in San Francisco, USA. The USA, China, South Korea, the United Kingdom, Australia and the Netherlands are the most important regions in the sharing economy. Europe and Finland in particular are still relatively small, but its 
popularity is expected to steadily increase in the areas of accommodation, transport, finance and household services.

There have been many changes in the sharing economy over the last 15 years. To some extent, the development was initiated by the shift from materialism to the behaviour of sharing goods, when people began to perceive the pressures of the environment, accompanied by a wide range of consumerism. Nevertheless, developing digital technology has been the driving force behind the sharing of the economy [5].

From different disciplines provide different definitions and terminology of the concept of the sharing economy [6]; [7]; [8], is therefore no agreement on a universal definition that would be appropriate for all [9]. Studies that have tried to discuss the definition of a sharing economy [10]; [11]; [12]. On the one hand, [13] argue that describing the phenomenon of the sharing economy is difficult, as the practice of this leisure sector is very diverse and constantly changing, and researchers do not set specific criteria for defining the concept of this phenomenon. On the other hand, understanding the concept of sharing an economy is very important and relevant. One of the possible definitions of the allegations made by Munoz and Cohen (2016) [14] who argue that the sharing economy should be understood as a socio-economic framework allowing the exchange of goods and services between individuals and organisations aimed at increasing the efficiency and optimization of under-utilised resources in society.

The sharing economy can be understood as an economic system with five characteristics. Firstly, it is a reasonable market on whose behalf the exchange of goods and services is established [3]. Secondly, the significant impact on capital opens up new opportunities for the sharing economy, where unused assets can be converted into cash and thus fully utilised. Third,people's contacts allow capital and labour to be supplied directly from a group of individuals as a substitute for thirdcountry corporations. Finally, sharing the economy eliminates the differences between people in private and work, those with work and casual jobs [3].

Sharing economy can be divided into three main cores:

1. The access economy (initiatives sharing under-utilised assets (material resources or skills) to optimise their use);

2. Platform economy (brokering decentralised exchanges between peers through digital platforms);

3. Community economy (coordination through non-contractual, non-hierarchical or unprofitable forms of interaction (work, exchange, etc.) [15].

Example of a sharing economy business

A business model of a sharing economy where the asset is shared by two persons: the owner of the property and the asset seeker (person interested in lending the property). The claimant receives information about the assets held by analysing the online analysis and examining product descriptions displayed on the websites of service providers

Are therefore a market services platform that both parties can use and through which payments are transferred? For example, Airbnb charges $6-12 \%$ of the booking fee and 3\% from each host for each successful transaction. The owner provides information about the property on the website and answers questions about the service or product, and the searcher contacts the relevant owner of the property and asks him to reserve the dwelling for a certain period of time for the agreed fee. In addition, the sharing economy is linked to both countries, thereby creating.

Example of a customer's journey sharing economy

Keski-Heikkilä (2018) [16] carried out a study which consistently used the sharing of economic platforms in both transport and accommodation. On the basis of this research, an example of customer travel will be discussed in order to further explore the sharing economy and its possibilities in the modern world

Keski-Heikkilä (2018) has chosen a destination for personal affairs, and the reason is the desire to visit relatives living in Zagreb, Croatia. Initially, the booking process began by examining various Airbnb lists and reviewing traditional hotels and apartments. 
In Croatia, it was decided to travel with Uber, which was chosen as a mode of transport for convenience and affordable prices. In Zagreb, Uber worked extremely well on the airport, and the quality of service for each driver was good in terms of convenience and accuracy. In some cases, safety has been a concern when drivers appear to have failed to comply with speed limits. For example, few drivers have complied with traffic rules. Nevertheless, drivers were happy to communicate with passengers and were happy to make recommendations on what to see and where to go in Zagreb, which allowed the author to taste local culture.

Fig.1 Airbnb business model

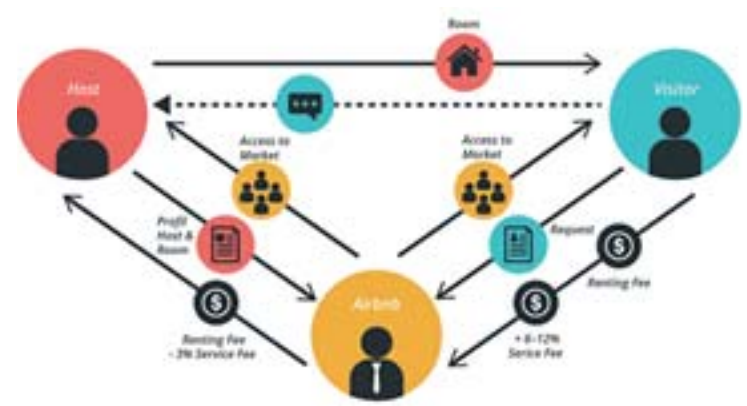

Websites are therefore a market services platform that both parties can use and through which payments are transferred. For example, Airbnb charges 6-12\% of the booking fee and 3\% from each host for each successful transaction. The owner provides information about the property on the website and answers questions about the service or product, and the searcher contacts the owner of the property concerned and asks him to reserve the dwelling for a certain period of time for the agreed fee. Addition, the sharing economy is linked to both countries, thereby building trust [17].

\section{CONCLUSIONS}

The sharing economy is constantly evolving, the main principles of the phenomenon are: more efficient use of available resources, transition from ownership to peer-sharing platforms. The sharing economy allows individuals to rent or borrow another property belonging to it. Thus, the sharing economy combines property owners and those seeking this particular asset.

The modern sharing economy is still developing, and the sharing of things is expected to be the future for many business areas. Sharing the economy offers many opportunities for Leisure and Hospitality, along with a few challenges faced by these organizations.

\section{REFERENCES}

[1] T.Geron, Will Ride-Sharing Apps Replace Car Ownership? 2012, https://www.forbes.com/sites/tomiogeron/2012/11/09/ study-airbnb-had-56-million-impact-on-san-francisco/?sh=b60324b3962a

[2] V. M. Lahti, J. Selosmaa. A fair share: Towards a new collaborative economy. Atena, 2020.

[3] A. Sundararajan. From Zipcar to the sharing economy. Harvard business review, 2013, 1(1), pp. 1-2.

[4] B. Cohen, E. Almirall, H. Chesbrough, The city as a lab: Open innovation meets the collaborative economy. California Management Review, 2016, 59(1), pp. 5-13. 
[5] K. Kelly, The Inevitable: Understanding the 12 technological forces that will shape our future. Viking. New York. 2016.

[6] R.Belk, Foreword: the sharing economy. The rise of the sharing economy: Exploring the challenges and opportunities of collaborative consumption,2018, pp. 9-12.

[7] L.Richardson, Performing the sharing economy. Geoforum, 2018, 67, pp. 121-129.

[8] I.P.Tussyadiah, Strategic self-presentation in the sharing economy: Implications for host branding. In Information and Communication Technologies in Tourism, Springer, Cham. 2016, pp. 695-708.

[9] D.Dredge \& S.Gyimóthy, The collaborative economy and tourism: Critical perspectives, questionable claims and silenced voices. Tourism recreation research, 2015, 40(3), pp. 286-302.

[10] R.Belk, Foreword: the sharing economy. The rise of the sharing economy: Exploring the challenges and opportunities of collaborative consumption, 2018, pp. 9-12.

[11] C.F. Breidbach, R.J. Brodie, Engagement platforms in the sharing economy: conceptual foundations and research directions. Journal of Service Theory and Practice, 2017, 27(4), pp. 761-777.

[12] J.Camilleri,B. Neuhofer, Value co-creation and co-destruction in the Airbnb sharing economy. Int. J. Contemp. Hospitality Manage,2017, 29(9), pp. 2322-2340.

[13] M.Herbert, I.Collin-Lachaud, Collaborative practices and consumerist habitus: An analysis of the transformative mechanisms of collaborative consumption. Recherche et Applications en Marketing (English Edition), 2017, 32(1), pp. 40-60.

[14] P.Muñoz, B.Cohen, Mapping out the sharing economy: A configurational approach to sharing business modeling. Technological Forecasting and Social Change, 2017, pp. 125, 21-37.

[15] C.J.Martin, The sharing economy: A pathway to sustainability or a nightmarish form of neoliberal capitalism?. Ecological economics, 2016, 121, pp. 149-159.

[16] E. J. Keski-Heikkilä, The challenges and possibilities of sharing economy for the travel intermediaries. 2018. https://www.theseus.fi/handle/10024/143480

[17] A. Stephany, The business of sharing: Making it in the new sharing economy. Springer, 2015 . 